\title{
Molecular biomarkers in the subsurface of the Salar Grande (Atacama, Chile) evaporitic deposits
}

\author{
Laura Sánchez-García • Christoph Aeppli • Victor Parro • David Fernández-Remolar • \\ Miriam García-Villadangos • Guillermo Chong-Diaz • Yolanda Blanco • \\ Daniel Carrizo
}

Received: 24 January 2018/ Accepted: 12 July 2018/Published online: 7 August 2018

(C) The Author(s) 2018

\begin{abstract}
The Late Miocene-Pliocene aged hyperarid evaporitic system of Salar Grande is a unique, halite-rich sedimentary basin in the Cordillera de la Costa of the Central Andes (Chile) whose biosedimentary record is poorly understood. The persistence of hyperacidity over millions of years, the hypersalinity, and the intense UV radiation make it a terrestrial analogue to assess the potential presence of organic matter in the halite deposits found on Mars. We investigated the occurrence and distribution of biomolecules along a 100-m depth drill down to the $\sim 9 \mathrm{Ma}$ old detrital deposits topped by $L a$ Soledad Formation (ESF). We have identified two well-defined mineralogical and geochemical units by
\end{abstract}

Responsible Editor: Susan Ziegler.

Laura Sánchez-García and Daniel Carrizo have contributed equally to this work.

Electronic supplementary material The online version of this article (https://doi.org/10.1007/s10533-018-0477-3) contains supplementary material, which is available to authorized users.

L. Sánchez-García · V. Parro · M. García-Villadangos ·

Y. Blanco · D. Carrizo $(\square)$

Centro de Astrobiología (CSIC-INTA), Carretera de

Ajalvir km 4, Torrejón de Ardoz, 28850 Madrid, Spain

e-mail: dcarrizo@cab.inta-csic.es

C. Aeppli

Bigelow Laboratory for Ocean Sciences, Maine, USA
$\mathrm{X}$-ray diffractometry (XRD) and ion chromatography: a nearly pure halite down to $40 \mathrm{~m}$, and a detrital one down to $100 \mathrm{~m}$ depth. One-dimensional GC-MS and two-dimensional GC $\times$ GC-TOF-MS gas chromatography-mass spectrometry techniques allowed us to detect a variety of lipidic compounds ( $n$-alkanes, $n$-alkanols, isoprenoids, steroids, and hopanoids), and a relative abundance of functionalized hydrocarbons ( $n$-fatty acids or $n$-aldehydes), mostly in the upper halite. We also detected biopolymers and microbial markers by fluorescence sandwich-microarray immunoassays. A dominant prokaryotic origin was associated with halophile bacteria and archaea, with minor contributions of lichens, macrophytes, or higher plants. The lipidic record was also imprinted by oxic (high pristane over phytane ratios) and saline (squalane, and mono-methyl $n$-alkanes) signatures. The vertical abundance and distribution of biomarkers in the Salar Grande was explained by a generalized effect of xeropreservation, combined with salt encapsulation in the upper halite deposits, or with protective organics-mineral interactions in the deeper detrital unit. The results contribute to the interpretation of

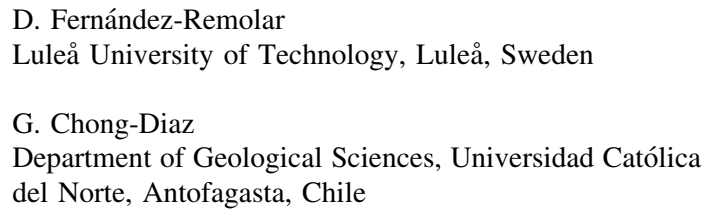

D. Fernández-Remolar

Luleå University of Technology, Luleå, Sweden

G. Chong-Diaz

Department of Geological Sciences, Universidad Católica del Norte, Antofagasta, Chile 
terrestrial bio-sedimentary records of halite deposits and their association to environmental conditions. The high potential for preservation of biosignatures at Salar Grande suggests that similar evaporitic deposits in Mars should be priority targets for searching for signs of life.

Keywords Lipidic biomarkers - Halite deposits . Salar Grande · Life detector chip · Planetary exploration $\cdot$ Mars

\section{Introduction}

Organics preservation over long geological periods is crucial for understanding the emergence and evolution of life on Earth (Peters et al. 2005a) as well as to investigate regional and global climate changes (González-Vila et al. 2003 and references therein). The key aspects that foster the preservation of organic matter (OM) and the different adaptation strategies in extreme environments can help to pinpoint extraterrestrial life signals (Summons et al. 2011). One approach to improve our knowledge about life establishment and adaptability in other planets is to exploit the environments on Earth resembling extraterrestrial counterparts. The use of planetary analogues assumes that microorganisms thriving in certain extreme conditions on Earth should be able to comparably develop in similar environments on other planetary bodies. The confirmed presence of water on Mars (Squyres et al. 2004; Prieto-Ballesteros et al. 2006; Martín-Torres et al. 2015), liquid in the past and (at least) frozen in present (Dundas et al. 2018), has raised the possibilities for the eventual existence of (extant or extinct) life on that planet.

Similarities between the Atacama Desert (Chile) and certain current Mars regions include extreme and prolonged aridity (Dunai et al. 2005), highly oxidizing chemistry, and intense UV radiation that promote high rates of oxidant production in the soil (Quinn et al. 2013; Georgiou et al. 2015, 2017) and a very low water activity (Navarro-González et al. 2003; Davila et al. 2008). The Mars halide deposits correspond to 5-20 m thick materials that, similar to the Atacama materials, were formed from the evaporation of isolated water masses, which were eventually supplied by ground aquifers (Osterloo et al. 2010). The Salar Grande is a
Neogene evaporitic basin located in the Cordillera de la Costa in Atacama, with persistence of hyperaridity over millions of years (Chong-Diaz et al. 1999; Dunai et al. 2005). Despite the extreme conditions, microbial habitats associated with halite are able to develop in certain hypersaline deposits in the Salar Grande (Davila et al. 2010; Parro et al. 2011a; FernándezRemolar et al. 2013; Crist-Christoph et al. 2016), related to deliquescence events (Davila et al. 2008, 2010) and sporadic rain events (Chong-Diaz et al. 1999). The potential of hypersaline environments to preserve biomolecules over geologically significant time scales makes the Salar Grande an interesting scenario to investigate biomolecular markers and taphonomic processes for the search for life vestiges on Earth or in planetary exploration.

Molecular markers constitute valuable, diagnostic tools as they encode information about ancient biodiversity, trophic associations, and environmental conditions (Engel and Macko 1997). From the high number of biomolecules produced by living organisms, lipids are of particular interest for their taxonomic specificity and potential for preservation (Brocks and Summons 2003). Lipids preserved in geological samples (geolipids) retain useful information about the biological sources and historical availability of oxygen, water, temperature, or salinity (Gaines et al. 2009). Much of that biological and environmental information is retained in specific hydrocarbon skeletons with potential for preservation over geologic time scales when diagenesis is mild (Peters et al. 2005a). Hence, hydrocarbon patterns are proposed as preferred biomarkers of extraterrestrial life (Georgiou and Deamer 2014), where shortchained hydrocarbons would act as simple molecular building blocks to form early protocells (Deamer and Georgious 2015). The study of lipidic biomarkers and environment-diagnostic ratios in the hyperarid and hypersaline Salar Grande would provide key information on the succession of biological communities over time, their correlation with environmental changes (e.g. sporadic wet events), or about how life may have thrived in the unique evaporitic system.

We have previously reported the presence of microbial markers down to $5 \mathrm{~m}$ depth at the borders of Salar Grande by using a multiplex antibodymicroarray immunoassay, the Life Detector Chip (LDChip) (Parro et al. 2011a). The LDChip contains more than 200 antibodies developed for the search of 
relatively well-preserved microbial structures and polymers (proteins, exopolysaccharides, or nucleic acids) from extant or extinct life in planetary exploration (Rivas et al. 2008; Parro et al. 2011b). LDChip is the core sensor of the Signs of Life Detector (SOLID) instrument, a mature and field-tested instrument for automatic processing of solid (soil, dust, powder) samples, extraction into a liquid solvent, and molecular biomarker detection by a fluorescent antibody microarray (Parro et al. 2005, 2011b). Detecting large biopolymers and microbial structures (regardless of their degree of preservation) with immunological methods in ancient evaporitic systems is a direct indication of their preservation potential and the feasibility of finding similar compounds in analogue martian salt deposits (Osterloo et al. 2010).

The Salar Grande is a 45-km-long (N-S axis), 4-kmwide evaporitic basin almost exclusively composed of massive halite, some of which pre-date to $\sim 9 \mathrm{Ma}$ (Chong-Diaz et al. 1999). Although many geological prospections have been performed in the area, all of them aimed to study the geochemical variables for industrial and mining purposes. Despite its potential to contribute new insights about taphonomy and preservation of biosignatures in saline deposits, to the best of our knowledge there are no studies on the geomicrobiology or biogeochemistry along the sedimentary record of Salar Grande. The objective was to investigate the bio-sedimentary record of this unique evaporitic deposit and to establish any possible association of the biomarkers profile with depth and the different stratigraphic units. Therefore, we determine the presence of molecular biomarkers (lipids and large biopolymers) along a vertical profile down to $\sim 100 \mathrm{~m}$, with particular interest in the large halite deposits at the upper part $(<4 \mathrm{Ma})$, and in the interface with the detrital underlayer (Sáez et al. 2012). We assessed the presence of signs of life (present or past) and their primary biosources, and discussed their occurrence and distribution within the mineralogical and geochemical context.

\section{Materials and methods}

Study area and geological settings

Salar Grande is located in the hyperarid belt of the Atacama Desert, at some $80 \mathrm{~km}$ south of Iquique $\left(20^{\circ} 13^{\prime} \mathrm{S}\right.$ and $70^{\circ} 09^{\prime} \mathrm{W}$ ) and at $650-750$ m.a.s.l. in the Cordillera de la Costa, Northern Chile (Fig. 1). The $180 \mathrm{~km}^{2}$ sedimentary basin is considered one of a series of "fossil salars", formerly Neogene lakes (Soledad, Pintados, Bellavista, Llamará, and Quillagua; Brüggen 1950), which are closely linked to the large hydrogeological system of the Central Depression located to the east.

As part of the Atacama Desert, this area has evolved since the Upper Paleogene as the main continental base level for the water recharge from the Precordillera and main Cordillera of the eastern belt of Northern Chile. The hyperarid environment has been described as a result of the systematic uplift of the High Andes, inducing the development of a rain shadow effect and the influence of the Hadley Cell and the Humboldt Current (Allmendinger and González 2010). All these circumstances together boosted climatic stability and the emergence of a hyperarid desert zone where the average annual rainfall is less than $1 \mathrm{~mm}$ (Hartley and Chong 2002). As a consequence, the water regime associated with the High Andes produced the development of huge alluvial fan systems associated to playa and saline lakes that evolve to salt flats (salares), where Salar Grande dates from the Late MiocenePliocene (Chong 1988). At present, no water recharge exists in the Salar Grande system, even when minimal underground inputs reach the basin from the east through an E-W fault system. Especially in winter, the Salar Grande receives a scarce surficial water supply in the form of dripping fogs formed in the Pacific Ocean, locally called "camanchaca".

The massive halite lies on top of terrigenous deposits, together conforming a stratigraphical formation developed during three different episodes (Chong-Diaz et al. 1999; Sáez et al. 1999). A first deposition consists of a red detrital bed, with carbonate, anhydrite sediments and lacustrine diatomite materials in the Miocene-Paleogene. A second deposition episode during the late Miocene contains breccias, gravels, marls and diatomites in a group known as the Quillaua Formation. Finally, these deposits were capped during the Pliocene to Pleistocene (Sáez et al. 2012) by the massive chloridebearing unit (La Soledad Formation) formed under hyperarid conditions. 

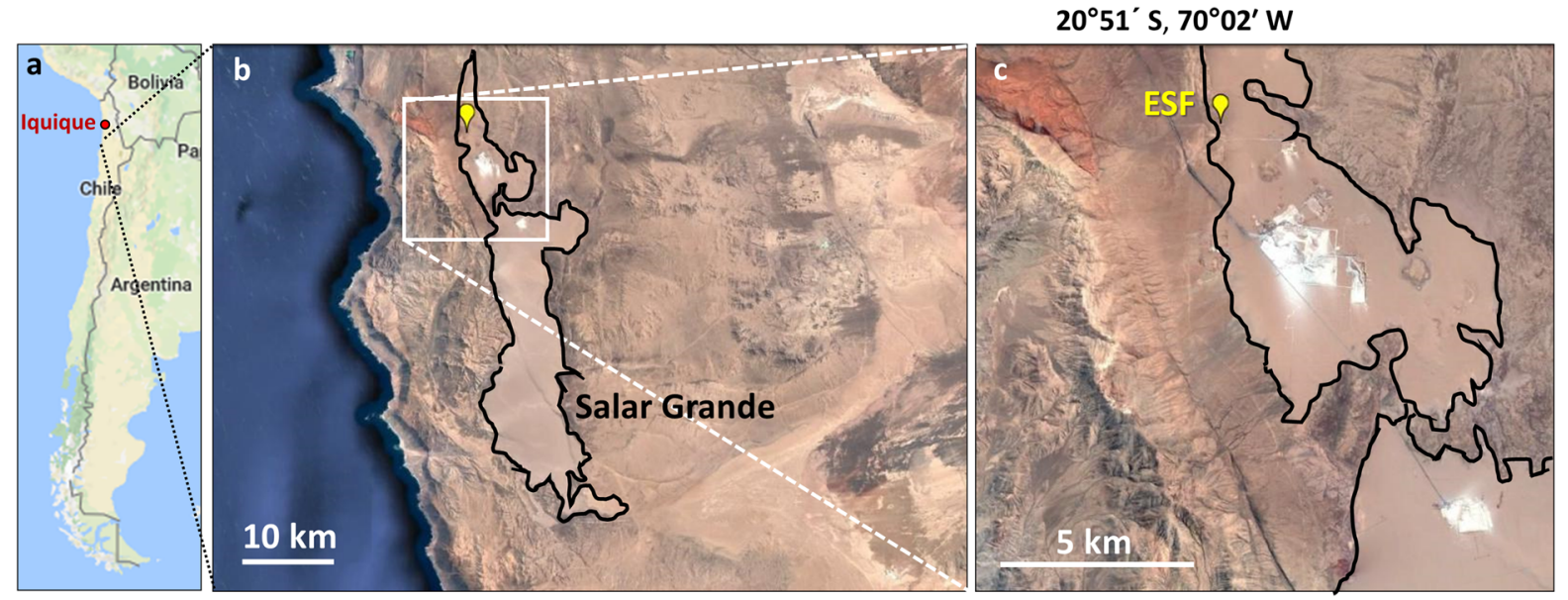

Fig. 1 Map of Chile (a), showing the location of Salar Grande (b) and the ESF drilling site (c), as satellite images (from Google Maps). White patches in $\mathrm{b}$ and $\mathrm{c}$ stand for local salt mines and document the abundance of salts in the studied area

Sample collection and approach

In 2008, a 100 m depth core was collected from $L a$ Soledad and Quillaua Formations (2051 S latitude, $70^{\circ} 02^{\prime} \mathrm{W}$ longitude) in the Salar Grande (ESF; Fig. 1) using a lubricant-free and solvent-cleaned destructive drill (Cheng et al. 2016). The sampling site is located in a previously described geological setting (e.g. Chong-Diaz et al. 1999), where the upper deposits ( $\geq 40 \mathrm{~m}$ ) are almost pure white halite (97-98\%), with rare sulphate glauberite, thenardite and polyhalite. Terrigenous sediments are almost absent in these deposits, except for the most surficial, where brown fractured crusts form upon eolian inputs and fogs dripping. The evaporitic halite deposits are considered to date $\sim 0.1$ to $0.2 \mathrm{Ma}$, whereas the age of the deeper detrital material may reach up to $\sim 9 \mathrm{Ma}$ (Sáez et al. 2012).

Samples containing cuttings and chips from the drill were collected every $2 \mathrm{~m}$ and temporarily stored at ambient temperature (ca. $3-30{ }^{\circ} \mathrm{C}$ ), until transported to $-20{ }^{\circ} \mathrm{C}$ freezers back in the laboratory (7 days later). Due to the large number of samples and logistic constraints such as timing and scheduling with the drilling company, sterile polyethylene jars were used for sampling instead of glassware material. Therefore, our approach to minimize contamination of the organic extracts was as follows: (i) collecting as large amount of drill cuttings as possible per container (800-1000 g) to dilute potential contaminants; (ii) transferring the samples to Teflon or glassware with solvent-cleaned (DCM and $\mathrm{MeOH}$ ) spoons once in the laboratory, and; (iii) performing organic extraction and analysis of the polyethylene jars as container blanks to identify and subtract plastic contaminants. Samples collected every $2 \mathrm{~m}$ were freeze-dried at $-20{ }^{\circ} \mathrm{C}$, and ground into powder using an agate pestle and mortar to obtain a homogeneous micrometer-sized powder. A subset of 12 samples was processed for mineral, geochemical, and lipidic analysis.

\section{Mineralogy and geochemistry}

The mineralogical characterization of the ESF samples was performed using a Bruker AXS D8-Focus $\mathrm{X}$-Ray Diffractometer (XRD) operating at $40 \mathrm{kV}$ and $40 \mathrm{~mA}$ with a $\mathrm{Cu}$ X-ray source $(\mathrm{Cu} \mathrm{K} \alpha 1,2$, $\lambda=1.54056 \AA$ ). All the XRD patterns were collected in the $2 \theta$-diffraction angle from $5^{\circ}$ to $70^{\circ}$, with a scanning step size of $0.01^{\circ}$.

The concentration of anions and low molecular weight organic acids were determined in leachates by ion chromatography (IC) as previously described (Parro et al. 2011a), with some modifications. Two g of each sample were suspended in $20 \mathrm{~mL}$ of IC-grade water (Sigma Aldrich, Cat. 00612), vortexed for 1-2 min, and then incubated with agitation for $2 \mathrm{~h}$. The leachates were centrifuged (4000 $g$ for $10 \mathrm{~min}$ at ambient temperature) and then filtered $(0.22 \mu \mathrm{m}$ PTFE) to remove the mineral particles. The clean supernatants were loaded into a Metrohm 861 
Advanced Compact Ion Chromatographer (Metrohm AG, Herisau, Switzerland) by an automatic loader, undiluted or at different dilution values, depending on the expected ion concentration. For all anions, a Metrosep A supp 7-250 column was used with $3.6 \mathrm{mM}$ sodium carbonate $\left(\mathrm{NaCO}_{3}\right)$ as eluent. Each sample was measured three times; each measurement at a different dilution to take the values that best fitted the calibration curve. The measurement error of the equipment for replicate samples was less than $1 \%$. The instrument was calibrated with a multi-anionic solution with 6-point concentrations curve for each anion and detection limits at few ppb level for all of them (not shown). The $\mathrm{pH}$ of the water solutions was measured with a pH-meter (WTW, GmbH \& Co. KG, Weilheim, Germany) after $24 \mathrm{~h}$ of solution stabilization.

The total organic carbon (TOC) determination was based on the loss-of-ignition method (drying at $105{ }^{\circ} \mathrm{C} / 16 \mathrm{~h}$ plus ignition at $440{ }^{\circ} \mathrm{C} /$ overnight; e.g. ASTM 2000) with some modifications. Here, the TOC (\% of dry weight) was estimated on the dry samples (oven at $60{ }^{\circ} \mathrm{C}, 72 \mathrm{~h}$ ), by differential weighing before and after combustion in a furnace at $550{ }^{\circ} \mathrm{C}$ for $8 \mathrm{~h}$ (Parro et al. 2011a).

Geolipids extraction, fractionation, and analysis

Solvent extractable lipids were recovered from $\sim 35$ g samples, by ultrasound extraction (three 35-min cycles at room temperature) with dichloromethane:methanol (5:1, v/v) (Martrat et al. 2004). After addition of internal standards (tetracosane- $\mathrm{D}_{50}$ and 2-hexadecanol), three consecutive extractions with $50 \mathrm{ml}$ of solvents were performed. The lipid extracts were concentrated using rotary evaporation and elemental sulfur removed with activated copper. The extracted samples were cleaned on silica columns ( $\sim 5 \mathrm{~cm}$ high, $60 \AA$ pore size, $60-100$ mesh) using hexane:dichloromethane $(4: 1)$ and pure dichloromethane as eluents of the saturated and polar fractions, respectively (Menor-Salván et al. 2010). The separated fractions were dried under $\mathrm{N}_{2}$ flow and transferred in hexane to GC-vials to be identified and quantified by gas chromatography-mass spectrometry (GC-MS and GC $\times$ GC-TOF-MS), with aid of external standards (see below) and spectra libraries (NIST14 MS and AMDIS v. 2.72).
The samples were analyzed by GC-MS using a 6850 GC system coupled to a 5975 VL MSD with a triple axis detector (Agilent Technologies), operating with electron ionization at $70 \mathrm{eV}$ and scanning from $m / z$ 50-650. The analytes were injected $(2 \mu \mathrm{L})$ and separated on a HP-5MS column ( $30 \mathrm{~m}, 0.25 \mathrm{~mm}$ i.d., $0.25 \mu \mathrm{m}$ film thickness) using $\mathrm{He}$ as a carrier gas at $1.1 \mathrm{~mL} \mathrm{~min}^{-1}$. The oven temperature was programmed from $40{ }^{\circ} \mathrm{C}(1.5 \mathrm{~min})$ to $150{ }^{\circ} \mathrm{C}$ at $15^{\circ} \mathrm{C}$ $\min ^{-1}$ (held $2 \mathrm{~min}$ ), then to $255^{\circ} \mathrm{C}$ at $5{ }^{\circ} \mathrm{C} \min ^{-1}$ (held $20 \mathrm{~min}$ ), and to $300{ }^{\circ} \mathrm{C}$ at $5{ }^{\circ} \mathrm{C} \mathrm{min}{ }^{-1}$ (held $20 \mathrm{~min}$ ). The injector temperature was $290{ }^{\circ} \mathrm{C}$, the transfer line $300{ }^{\circ} \mathrm{C}$, and the MS source $240{ }^{\circ} \mathrm{C}$. For quantification, external standards of $n$-alkanes $\left(\mathrm{C}_{10}\right.$ to $\mathrm{C}_{40}$ ), $n$-fatty acids (even $\mathrm{C}_{4}$ to $\mathrm{C}_{24}$ ), and $n$-alkanols $\left(\mathrm{C}_{10}, \mathrm{C}_{14}, \mathrm{C}_{18}\right.$, and $\left.\mathrm{C}_{20}\right)$ were used to obtain calibration curves. Analytical blanks were run in parallel to the samples extractions, as laboratory controls, and the little amounts of certain $n$-alkanes detected were subtracted from the samples extracts. The container blanks revealed presence of phthalates and a few $n$ alkenes, poly-methyl alkanes, and polyunsaturated fatty acids. Fortunately, no significant contamination was detected as target analytes $(\leq 10 \%)$. Recoveries of the internal standard of alkanes (i.e. tetracosaneD50) averaged $66 \pm 29$ per cent.

In addition to GC-MS analysis, two-dimensional gas chromatography $(\mathrm{GC} \times \mathrm{GC}-\mathrm{TOF}-\mathrm{MS})$ was run on one sample from each mineralogical unit to provide better separation for identification and relative quantification of saturates (Aeppli et al. 2014). The selection of the two particular samples (19 and $95 \mathrm{~m}$ depth) was based on logistical constraints, as they had sufficient material remaining after previous geochemical and molecular analyses. Whereas regular GC-MS can satisfactorily resolve $n$-alkanes or $n$-fatty acids, higher resolution techniques are needed to detect heavier and more complex molecules such as hopanoids or steranes. To accomplish this, two samples were injected in a GC $\times$ GC system coupled to a time-of-flight (TOF) mass spectrometer (Pegasus 4D GC $\times$ GC, Leco Corporation, St. Joseph/MI, USA). About $2 \mu \mathrm{L}$ of the lipid extract of each sample was injected in a split/splitless injector at $320{ }^{\circ} \mathrm{C}$ and separated on an Rxi-1 ms column in the first dimension (60 m length, $0.25 \mathrm{~mm}$ i.d., $0.25 \mu \mathrm{m}$ film; Restek Corp, Bellafonte/PA) and a BPX-50 column in the second dimension ( $0.4 \mathrm{~m}$ length, $0.1 \mathrm{~mm}$ i.d., $0.1 \mu \mathrm{m}$ film; SGE Analytical Science). Ultrapure helium at a 
constant flow $\left(1 \mathrm{~mL} \mathrm{~min}^{-1}\right)$, and the following temperature program were used: $5 \mathrm{~min}$ at $70{ }^{\circ} \mathrm{C}$, ramped to $320{ }^{\circ} \mathrm{C}$ at $0.75{ }^{\circ} \mathrm{C} \mathrm{min}{ }^{-1}$ (held $15 \mathrm{~min}$ ). A modulation time of $20 \mathrm{~s}$ was used. The second-dimension oven and the modulator were operated at a constant offset of 5 and $20{ }^{\circ} \mathrm{C}$, respectively, relative to the GC oven. Mass spectra were collected at a sampling rate of $50 \mathrm{~Hz}$. The biomarker compounds (i.e. hopanoids and dia-/steranes; Table 2) were identified based on established elution order (Eiserbeck et al. 2012) and using authentic standards (Aeppli et al. 2014), and the $\mathrm{GC} \times \mathrm{GC}-\mathrm{TOF}-\mathrm{MS}$ peaks were manually integrated using the ChromaTOF software (Leco). Further material and methodological details including quality control are described elsewhere (Aeppli et al. 2014).

\section{Multiplex fluorescent sandwich-microarray} immunoassay

The ESF subsurface samples were analyzed by fluorescent sandwich microarray immunoassay with LDChip200 (Parro et al. 2008a, 2011a), to interrogate a panel of about 200 antibodies raised to bind to biological polymers and microbes from living or well preserved dead life structures (Rivas et al. 2008). The LDChip200 contained 177 polyclonal antibodies (purified IgG fraction) produced from: (i) whole microbial cells including strains of the most relevant phylogenetic groups of bacteria and archaea, (ii) endospores and exospores from Gram-positive bacteria, (iii) extracellular polymers such as exopolysaccharides (EPS), (iv) crude environmental extracts (from soils, water, sediments, rocks, biofilms) from extreme terrestrial analogue environments for Mars (Parro et al. 2011a; Blanco et al. 2015b), (v) conserved proteins and peptides involved in key metabolisms (iron and sulfur oxidation and reduction, nitrogen fixation, or hydrogen utilization), and (vi) 39 preimmune sera (IgG fraction) as negative controls (see Table S1 for detailed description). All antibodies were purified by protein A affinity columns (IgG fraction), fluorescently labelled, titrated, and their limit of detection determined individually with the corresponding target following standard immunological procedures in antibody microarray format (Rivas et al. 2008).

LDChip is a shotgun antibody microarray immunosensor, that is, a system of multiple probes to "fish" multiple, sometimes unknown, targets.
Antibodies mostly polyclonal and a variety of targets, including biological polymers and strains of extremophile and mesophile microbes covering a wide range of metabolisms and phylogeny, were selected to increase the success of detecting any microbial remain in natural samples, either for environmental monitoring and/or for signs of life detection in planetary exploration (Rivas et al. 2008; Parro et al. 2008b, 2011b). Different versions of LDChip have been tested in multiple field campaigns in Rio Tinto (Parro et al. 2008a), Atacama Desert (Parro et al. 2011a) Deception Island (Blanco et al. 2012), or Spanish water reservoirs (Blanco et al. 2015a), and it has been implemented for automatic in situ analysis in the instrument SOLID (Signs of Life Detector; Parro et al. 2008b), in e.g. Atacama (Parro et al. 2011a), or Rio Tinto (Parro et al. 2011b). The detailed protocol for the analysis of the Salar Grande samples with LDChip200 is described in Blanco et al. (2015b). Briefly, up to $0.5 \mathrm{~g}$ of each ESF sample was extracted by ultrasonication with $2.5 \mathrm{~mL}$ of extraction buffer (80 mM Tris- $\mathrm{HCl}, 60 \mathrm{mM} \mathrm{NaCl}, 0.2 \%$ Tween 20 ). The suspension was filtered $(5 \mu \mathrm{m})$ and $50 \mu \mathrm{L}$ of the filtrate incubated with LDChip200 for $1 \mathrm{~h}$, and then washed with the same buffer. A second $1 \mathrm{~h}$ incubation with $50 \mu \mathrm{L}$ fluorescent tracer antibodies was carried out and, after a final wash, the positive immunodetections were read out with the GenePix 4100A Microarray scanner. The relative fluorescence-intensity values from each of the antibody spots on the LDChip200 were quantified and plotted to generate a kind of immunogram (Fig. S5) characteristic of each sample (Parro et al. 2011a). The results were finally represented as a color-patterned heat map for a better visualization.

\section{Results}

Mineralogy and geochemistry in the Salar Grande

The XRD analysis indicated that the most abundant mineral phases in ESF samples corresponded to: halite $(\mathrm{NaCl})$, albite $\left(\mathrm{NaAlSi}_{3} \mathrm{O}_{8}\right)$, quartz $\left(\mathrm{SiO}_{2}\right)$, gypsum $\left(\mathrm{CaSO}_{4} \cdot 2 \mathrm{H}_{2} \mathrm{O}\right)$, anhydrite $\left(\mathrm{CaSO}_{4}\right)$, bromian chlorargyrite $(\mathrm{Ag}(\mathrm{Cl}, \mathrm{Br}))$, and glauberite $\left(\mathrm{Na}_{2} \mathrm{Ca}\left(\mathrm{SO}_{4}\right)_{2}\right)$. The mineralogical profile revealed two compositional units, (i) massive halite deposits containing bromian chlorargyrite (0-40 m depth), and (ii) detrital deposits 
including debris mainly from albite and quartz (40-100 m depth) (Fig. 2a).

The ion chromatography analysis (IC) provided values of inorganic ions well differentiated between the two mineralogical units; the upper halite-rich unit was clearly dominated by chlorides (14-35 $\mathrm{mg} \mathrm{g}^{-1}$ of dry weight; Fig. 2b), whereas the concentrations of nitrate $\left(\leq 0.011 \mathrm{mg} \mathrm{g}^{-1}\right)$ and sulphate $(0.04-0.35 \mathrm{mg}$ $\mathrm{g}^{-1}$ ) were much lower (Fig. 2c, d). In contrast, the deepest detrital unit was characterized by larger concentrations of nitrate $\left(0.42-4.0 \mathrm{mg} \mathrm{g}^{-1}\right)$ and sulphate $\left(0.71-3.5 \mathrm{mg} \mathrm{g}^{-1}\right)$, and chloride amounts one to two orders of magnitude lower than in the upper halite (0.29-2.5 mg g $\left.{ }^{-1}\right)$. Low concentrations of two small organic ions (i.e. acetate and propionate; Fig. 2e) were also detected; acetate $(0.048-1.1 \mu \mathrm{g}$ $\mathrm{g}^{-1}$ ) in both the upper (19 and $35 \mathrm{~m}$ depth) and lower (61 and $95 \mathrm{~m}$ depth) units, and propionate $(0.26 \mu \mathrm{g}$ $\mathrm{g}^{-1}$ ) at only $61 \mathrm{~m}$ depth (Table S2).

Total organic carbon (TOC) varied from 0.1 to $3.8 \%$ dry weight along the ESF profile (Table 1). Clear compositional differences were observed between the two sedimentary units (Fig. 3a), with the detrital deposits containing one order of magnitude more TOC (2.6-3.8\%) than the upper halite $(0.1-1.2 \%)$.
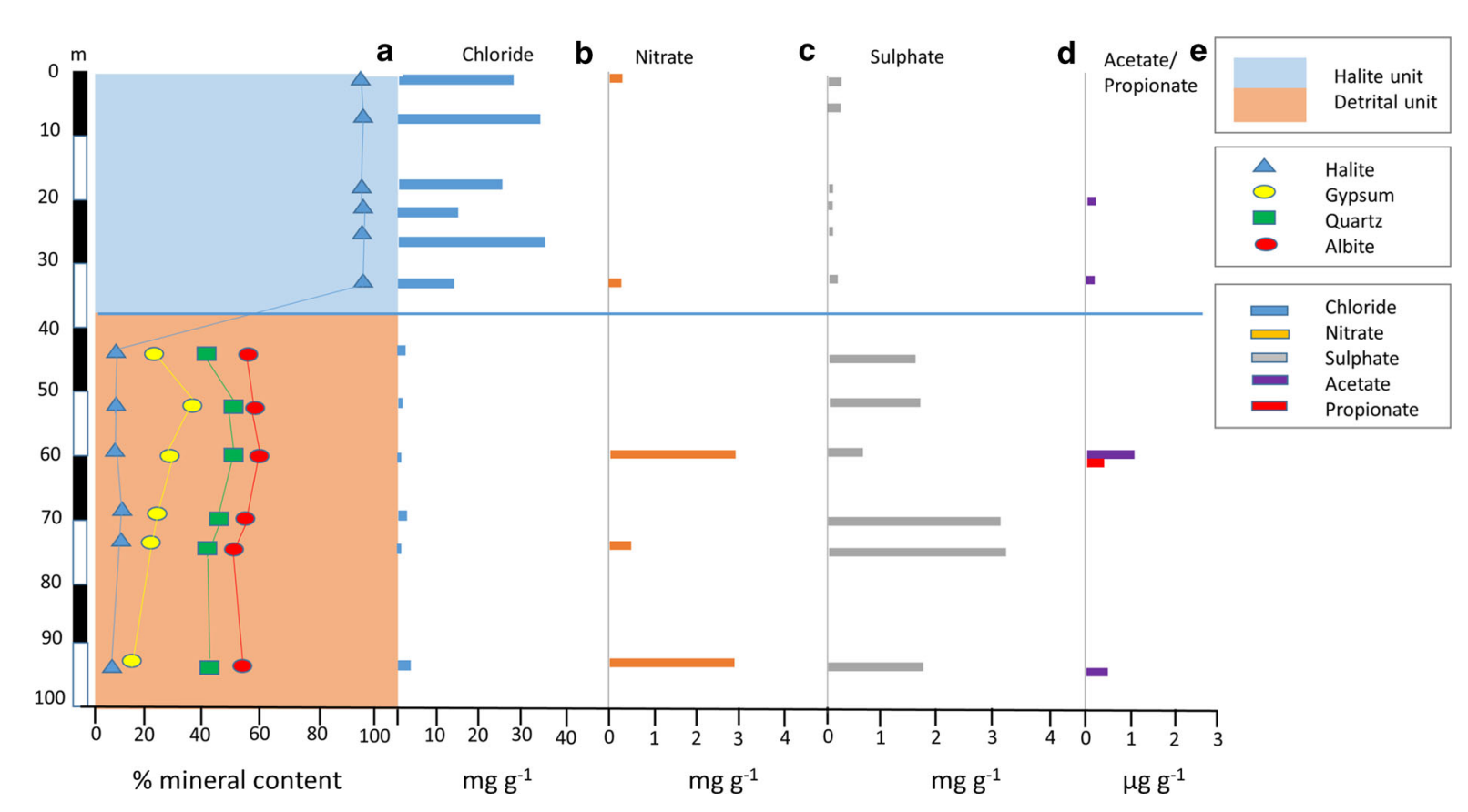

Fig. 2 Geochemical profile showing a mineralogical scatterplot (a) and bar diagrams of inorganic (b-d) and organic anions (e) along the ESF drill core
Lipid biomarkers profile in the Salar Grande at ESF

The molecular analysis of geolipids enabled the identification of about 100 organic compounds $(n$ alkanes, $n$-fatty acids, $n$-aldehydes, $n$-alkanols, isoprenoids, steroids, and hopanoids) by GC-MS (Tables S3-S8) and GC $\times$ GC-TOF-MS (Table 2).

\section{n-Alkanes and functionalized lineal hydrocarbons}

The $n$-alkanes family was found to be present in total concentrations ranging from 1.28 to $1906 \mu \mathrm{g} \mathrm{g}^{-1}$ of TOC, with the largest content at $19 \mathrm{~m}$ (Table 1). The distribution of $n$-alkanes varied among the samples units ranging from $\mathrm{C}_{12}$ to $\mathrm{C}_{34}$ was observed in all samples but those at 17 and $69 \mathrm{~m}$ depth. These two samples showed shorter chain length and a maximum peak at $\mathrm{C}_{18}$, in contrast to the general dominance of the $\mathrm{C}_{23}$ peak. Other even peaks such as $\mathrm{C}_{20}, \mathrm{C}_{24}$ or $\mathrm{C}_{26}$ were secondarily abundant in most of the samples (Fig. S1). The sample at $19 \mathrm{~m}$, the richest in $n$-alkanes (Fig. 3b), exhibited a different unimodal distribution with maximum at $\mathrm{C}_{29}$, and a secondary peak at $\mathrm{C}_{23}$. The ratio of even and low-molecular weight (LMW) $n$ (Fig. S1), where a general even preference of carbon 
Table 1 Concentrations ( $\mu \mathrm{g} \mathrm{g}^{-1}$ of TOC) and compositional distributions of lipid biomarkers (GC-MS) in the ESF core samples

\begin{tabular}{|c|c|c|c|c|c|c|c|c|c|c|c|c|}
\hline & \multicolumn{6}{|c|}{ Halite } & \multicolumn{6}{|c|}{ Detrital } \\
\hline & $1 \mathrm{~m}$ & $9 \mathrm{~m}$ & $17 \mathrm{~m}$ & $19 \mathrm{~m}$ & $27 \mathrm{~m}$ & $35 \mathrm{~m}$ & $45 \mathrm{~m}$ & $53 \mathrm{~m}$ & $61 \mathrm{~m}$ & $69 \mathrm{~m}$ & $75 \mathrm{~m}$ & $95 \mathrm{~m}$ \\
\hline TOC (\% dw) & 1.2 & 0.10 & 0.20 & 0.15 & 0.18 & 0.29 & 2.6 & 2.8 & 3.1 & 3.2 & 3.8 & 3.0 \\
\hline$n$-alkanes & 41.1 & 163 & 44.5 & 1906 & 37.0 & 267 & 6.51 & 6.58 & 41.6 & 1.28 & 6.13 & 43.0 \\
\hline fatty acids ${ }^{\mathrm{a}}$ & 2.93 & 30.1 & 33.1 & 47.1 & 26.1 & 11.6 & 0.906 & 3.18 & 1.19 & 3.71 & 0.507 & 1.59 \\
\hline$n$-alkanols & 6.73 & 9.00 & 14.6 & 58.4 & 130 & 10.7 & 4.08 & 2.29 & 2.15 & 1.26 & 1.87 & 1.03 \\
\hline$n$-aldehydes & 1.91 & 936 & 3.00 & 3.43 & 3.89 & 0.972 & 0.514 & 0.115 & 0.033 & 0.101 & 0.109 & 0.045 \\
\hline steroidls $^{\mathrm{b}}$ & nd & 21 & 30 & 13 & 14 & 10 & 0.54 & nd & 2.1 & 1.0 & 0.48 & 1.8 \\
\hline Pristane $(\mathrm{Pr})$ & 10.2 & 110 & 32.5 & 30.3 & 23.3 & 11.8 & 4.25 & 2.80 & 1.18 & 2.37 & 2.18 & 1.39 \\
\hline Phytane (Ph) & 2.77 & 4.58 & 4.00 & 1.11 & 1.67 & 1.52 & 0.207 & 0.143 & 0.064 & 0.189 & 0.146 & 0.098 \\
\hline Crocetane & nd & 20.0 & 6.50 & 16.0 & 13.9 & 6.55 & 1.08 & 1.47 & 1.18 & 1.64 & 0.741 & 1.31 \\
\hline Squalane & nd & 42.0 & 31.5 & 23.3 & 21.7 & 14.5 & 1.35 & 1.86 & 2.03 & 0.726 & 1.27 & 2.09 \\
\hline $\mathrm{Pr} / \mathrm{Ph}$ & 3.7 & 24 & 8.1 & 27 & 14 & 7.8 & 21 & 20 & 19 & 13 & 15 & 14 \\
\hline Even $\leq \mathrm{C}_{20} /$ Odd $\geq \mathrm{C}_{27}^{\mathrm{c}}$ & 3.6 & 0.98 & $*$ & 0.03 & 9.5 & 0.80 & 0.76 & 2.9 & 0.84 & $*$ & 0.28 & 1.6 \\
\hline
\end{tabular}

nd: not detected

*Asterisks stand for unvalid Even $\leq \mathrm{C}_{20} / \mathrm{Odd} \geq \mathrm{C}_{27}$ ratios resulting from the lack of detection of HMW alkanes

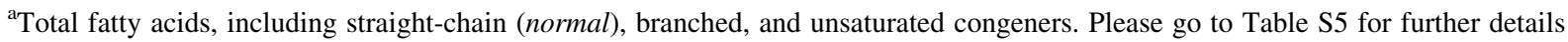

${ }^{\mathrm{b}}$ Total steroidls, including $\beta$-sitosterol (24-Ethylcholest-5-en-3 $\beta$-ol) and stigmastanol derivatives (stigmastanol [24 $\alpha$ ethylcholestanol]; stigmastan-7-one, and stigma-3,5-dien-7-one). Please go to Table $\mathrm{S} 8$ for further details

${ }^{\mathrm{c}}$ Even and low-molecular weight (LMW) $n$-alkanes $\left(\mathrm{C}_{16}-\mathrm{C}_{20}\right)$ over odd and high-molecular weight $n$-alkanes $\left(\mathrm{C}_{27}-\mathrm{C}_{31}\right)$

alkanes $\left(\mathrm{C}_{16}-\mathrm{C}_{20}\right)$ over odd and high-molecular weight (HMW) $n$-alkanes $\left(\mathrm{C}_{27}-\mathrm{C}_{31}\right)$ (even- $\leq \mathrm{C}_{20}$ l odd $\geq \mathrm{C}_{27}$ ) showed values ranging from 0.03 to 9.5 (Table 1), with higher values detected at $1 \mathrm{~m}, 35 \mathrm{~m}$, and to a larger extent at $27 \mathrm{~m}$ depth (Fig. S3 a). A wide variety of branched $n$-alkanes with different combinations of alkyl units (Table S4) were also detected in the organic extracts, including a series of short and mid-chained mono-methyl $n$-alkanes (MMA- $\mathrm{C}_{13}$, MMA- $\mathrm{C}_{14}$, MMA-C $\mathrm{C}_{18}$ and MMA- $\mathrm{C}_{20}$ ), and branched alkanes with quaternary carbon (BAQCs).

We measured concentrations of $n$-fatty acids ranging from 0.51 to $47 \mu \mathrm{g} \mathrm{g}^{-1}$ of TOC (Fig. 3c) in chains lengths from $\mathrm{C}_{12}$ to $\mathrm{C}_{24}$ (Table S5). An even-over-odd predominance was observed along the whole profile, with a main peak at $n-\mathrm{C}_{16}$ and a secondary peak at $n$ $\mathrm{C}_{18}$ (Fig. S2). Together with the straight-chain compounds, pairs of iso-/anteiso- fatty acids were observed for the 15 and 17 carbon units (Table S5), at lower concentration than the normal $\mathrm{C}_{15}$ and $\mathrm{C}_{17}$ counterparts (Fig. S2). In addition, monounsaturated fatty acids (i.e. $\mathrm{C}_{16: 1}, \mathrm{C}_{18: 1}$, and $\mathrm{C}_{20: 1}$ ) were also identified at all depths, at generally lower concentration than the saturated homologous (Table S5). All fatty acids, including the branched and monounsaturated congeners were clearly more abundant in the halite versus the detrital unit (Fig. 3c-e).

Other aliphatic families were also detected at larger concentrations in the halite than in the detrital unit. Short chains of $n$-alkanols $\left(\mathrm{C}_{10}-\mathrm{C}_{18}\right)$ were found at $1.03-130 \mu \mathrm{g} \mathrm{g}^{-1}$ of TOC (Fig. 3f), with a general dominance of the $\mathrm{C}_{16}$ peak (Table S6). A few shortchained $n$-aldehydes $\left(\mathrm{C}_{11}-\mathrm{C}_{14}\right.$; Table $\left.\mathrm{S} 7\right)$ varied from 0.03 to $9 \mu \mathrm{g} \mathrm{g}^{-1}$ of TOC) with depth (Fig. $3 \mathrm{~g}$ ).

\section{Acyclic isoprenoids}

Acyclic isoprenoids detected in the ESF core samples included pristane $\left(\mathrm{Pr}, \mathrm{C}_{19}\right)$, phytane $\left(\mathrm{Ph}, \mathrm{C}_{20}\right)$, crocetane $\left(\mathrm{C}_{20}\right)$, and squalane $\left(\mathrm{C}_{30}\right)$. Pristane was found in larger concentrations $\left(1.18-110 \mu \mathrm{g} \mathrm{g}^{-1}\right.$ of TOC) than phytane (0.064-4.58 $\mu_{\mathrm{g} \mathrm{g}^{-1}}$ of TOC) (Fig. 4a, b), that resulted into $\mathrm{Pr} / \mathrm{Ph}$ ratios larger than the unit (3.7-27; Table 1) and showed larger variability in the halite unit (Fig. S3 b). The irregularly branched $\mathrm{C}_{20}$ isoprenoid crocetane was detected at all depths but the most surficial at concentrations ranging from 0.74 to $20 \mu \mathrm{g} \mathrm{g}^{-1}$ of TOC (Fig. 4c), similarly to the tail-to- 

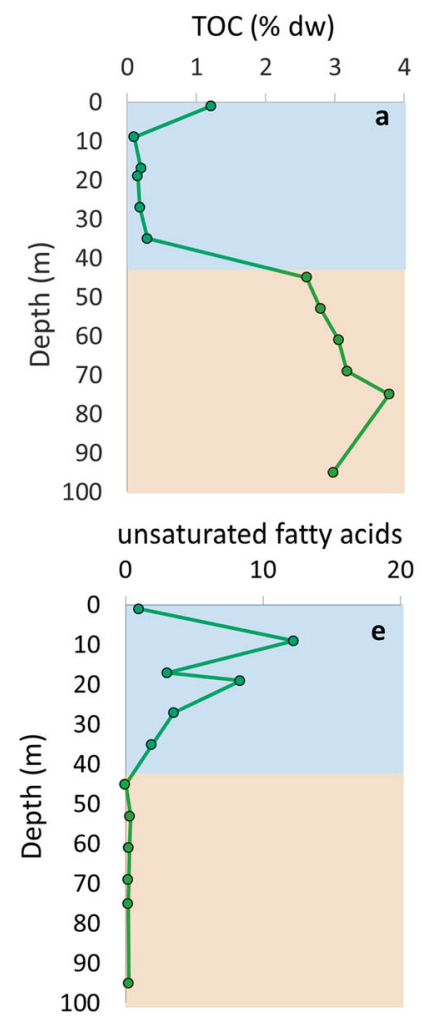
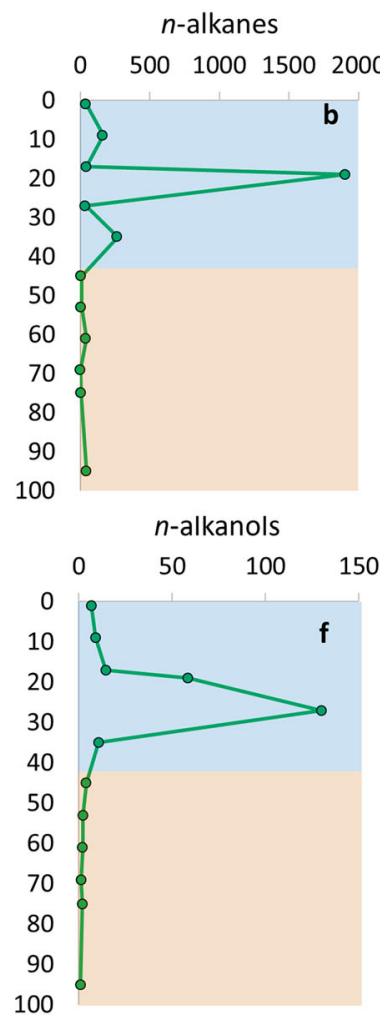

Fig. 3 Total organic carbon (TOC, as \% of dry weight) and lipids concentration and compositional distributions in the ESF drill profile ( $\mu \mathrm{g} \mathrm{g}^{-1}$ of TOC), where the halite and detrital units

tail linked $\mathrm{C}_{30}$ isoprenoid squalane $\left(0.73-42 \mu \mathrm{g} \mathrm{g}^{-1}\right.$ of TOC; Fig. 4d). The four isoprenoids were one order of magnitude more abundant in the halite versus the detrital unit.

\section{Steroids and hopanoids}

A few steroids such as $\beta$-sitosterol (24-Ethylcholest-5en-3 $\beta$-ol), stigmastanol (24-Ethyl-5 $\alpha$-cholestan-3 $\beta$ ol), stigmastan-7-one, and stigmasta-3,5-dien-7-one (Table S8) were measured by regular GC-MS at concentrations $\leq 30 \mu \mathrm{g} \mathrm{g}^{-1}$ of TOC (Fig. 3h). $\beta$ sitosterol was generally present throughout the ESF core, although at larger concentrations in the halite unit, whereas stigmastanol and their homologous ketones were basically found only in the upper halite (Fig. S4). The better resolution of the GC $\times$ GC-TOFMS allowed for a further characterization of the neutral fraction in the two samples at $19 \mathrm{~m}$ (halite) and $95 \mathrm{~m}$ (detrital unit) depth. In addition to the lipidic families already identified by GC-MS, the GC $\times$ GC-
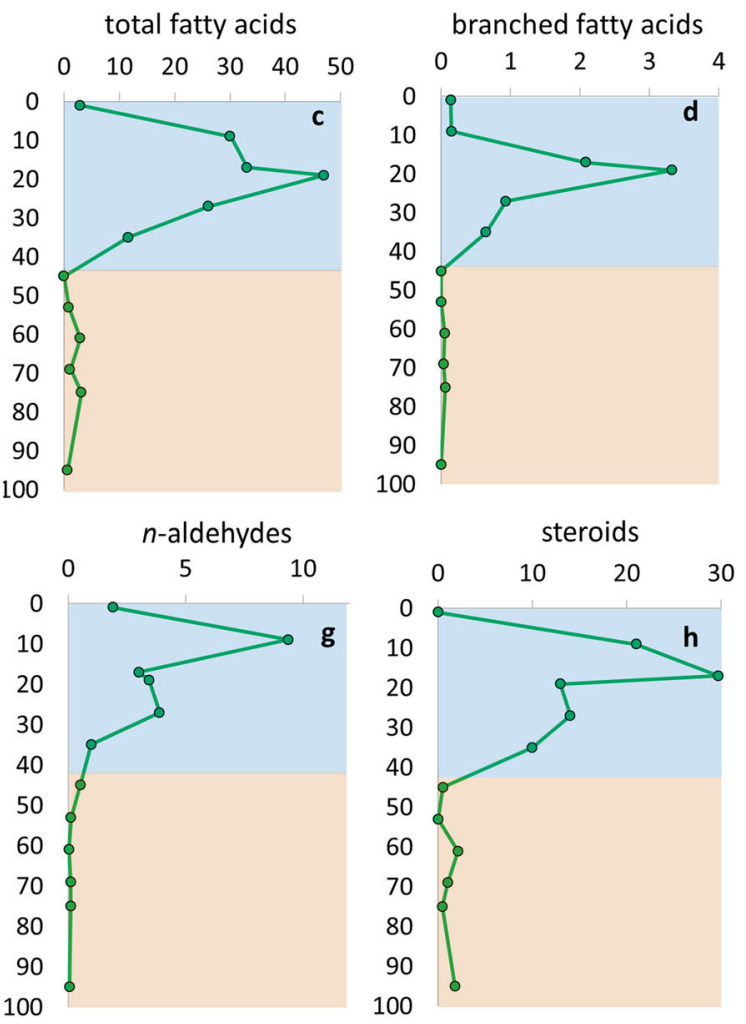

are represented by shaded blue and shaded orange areas, respectively. (Color figure online)

TOF-MS enabled the measurement of hopanoids, steranes, and diasteranes by analysis of the corresponding mass traces (Fig. 5). Hopanoids and steranes are useful biomarkers commonly employed to investigate sources of petroleum hydrocarbons in the environment (Wang et al. 2006). In both mineralogical units at ESF, steranes and diasteranes ranging from $\mathrm{C}_{27}$ to $\mathrm{C}_{29}$ were detected together with hopanes from $\mathrm{C}_{27}$ to $\mathrm{C}_{35}$ (Table 2). As common in biomarker analysis, we did not quantify these compounds on an absolute basis, but determined peak areas of hopanoids (on $\mathrm{m} / \mathrm{z} 191$ ) and steranes (on $\mathrm{m} / \mathrm{z} 217$ or 218), and created ratios of peaks for comparison of the biomarker distribution in the different samples. This use of relative abundance of individual hopanes and steranes allowed for discriminating between the dominant sources and microbial processing extent. For example, the peak of the mostly-prokaryotic hopanes (measured at $\mathrm{m} / \mathrm{z} 191$; Fig. 5a) was more than five times larger than that of the mostly-eukaryotic steranes (measured at $\mathrm{m} / \mathrm{z} 217$; Fig. 5 b) in both 
Table 2 Hopanes $(\mathrm{m} / \mathrm{z}$ 191) and steranes $(\mathrm{m} / \mathrm{z}, 217$ and 218) identified by GC

$\times$ GC-TOF-MS in the ESF samples. Please note that no units are reported as the analysis was semiquantitative

\begin{tabular}{|c|c|c|}
\hline Abbreviation & Name & Formula \\
\hline \multicolumn{3}{|l|}{ Hopanoids } \\
\hline $\mathrm{Tm}$ & $17 \alpha(\mathrm{H})-22,29,30$-trisnorhopane & $\mathrm{C}_{27} \mathrm{H}_{46}$ \\
\hline Ts & $18 \alpha(\mathrm{H})-22,29,30$-trisnorneohopane & $\mathrm{C}_{27} \mathrm{H}_{46}$ \\
\hline $\mathrm{NH}$ & $17 \alpha(\mathrm{H}), 21 \beta(\mathrm{H})-30$-norhopane & $\mathrm{C}_{29} \mathrm{H}_{50}$ \\
\hline $\mathrm{C}_{29}$-Ts & $18 \alpha(\mathrm{H}), 21 \beta(\mathrm{H})-30$-norneohopane & $\mathrm{C}_{29} \mathrm{H}_{50}$ \\
\hline $\mathrm{H}$ & $17 \alpha(\mathrm{H}), 21 \beta(\mathrm{H})$-hopane & $\mathrm{C}_{30} \mathrm{H}_{52}$ \\
\hline $\mathrm{HH}(\mathrm{S} / \mathrm{R})$ & $17 \alpha(\mathrm{H}), 21 \beta(\mathrm{H})-22 \mathrm{~S} / \mathrm{R}$-homohopane & $\mathrm{C}_{31} \mathrm{H}_{54}$ \\
\hline $2 \mathrm{HH}(\mathrm{S} / \mathrm{R})$ & $17 \alpha(\mathrm{H}), 21 \beta(\mathrm{H})-22 \mathrm{~S} / \mathrm{R}$-bishomohopane & $\mathrm{C}_{32} \mathrm{H}_{56}$ \\
\hline $3 \mathrm{HH}(\mathrm{S} / \mathrm{R})$ & $17 \alpha(\mathrm{H}), 21 \beta(\mathrm{H})-22 \mathrm{~S} / \mathrm{R}$-trishomohopane & $\mathrm{C}_{33} \mathrm{H}_{58}$ \\
\hline $4 \mathrm{HH}(\mathrm{S} / \mathrm{R})$ & $17 \alpha(\mathrm{H}), 21 \beta(\mathrm{H})-22 \mathrm{~S} / \mathrm{R}$-tetrakishomohopane & $\mathrm{C}_{34} \mathrm{H}_{60}$ \\
\hline \multicolumn{3}{|l|}{ Steranes } \\
\hline $\mathrm{C}_{27} \alpha \beta \beta(\mathrm{S} / \mathrm{R})$ & $5 \alpha(\mathrm{H}), 14 \beta(\mathrm{H}), 17 \beta(\mathrm{H})-20 \mathrm{~S} / \mathrm{R}$-cholestane & $\mathrm{C}_{27} \mathrm{H}_{48}$ \\
\hline $\mathrm{C}_{28} \alpha \alpha \alpha(\mathrm{S} / \mathrm{R})$ & 24-methyl-5 $\alpha(\mathrm{H}), 14 \alpha(\mathrm{H}), 17 \alpha(\mathrm{H})-20 \mathrm{~S} / \mathrm{R}$-cholestane & $\mathrm{C}_{28} \mathrm{H}_{50}$ \\
\hline $\mathrm{C}_{28} \alpha \beta \beta(\mathrm{S} / \mathrm{R})$ & 24-methyl-5 $\alpha(\mathrm{H}), 14 \beta(\mathrm{H}), 17 \beta(\mathrm{H})-20 \mathrm{~S} / \mathrm{R}$-cholestane & $\mathrm{C}_{28} \mathrm{H}_{50}$ \\
\hline $\mathrm{C}_{29} \alpha \alpha \alpha(\mathrm{S} / \mathrm{R})$ & 24-ethyl-5 $\alpha(\mathrm{H}), 14 \alpha(\mathrm{H}), 17 \alpha(\mathrm{H})-20 \mathrm{~S} / \mathrm{R}$-cholestane & $\mathrm{C}_{29} \mathrm{H}_{52}$ \\
\hline $\mathrm{C}_{29} \alpha \beta \beta(\mathrm{S} / \mathrm{R})$ & 24-ethyl-5 $\alpha(\mathrm{H}), 14 \beta(\mathrm{H}), 17 \beta(\mathrm{H})-20 \mathrm{~S} / \mathrm{R}$-cholestane & $\mathrm{C}_{29} \mathrm{H}_{52}$ \\
\hline \multicolumn{3}{|l|}{ Diasteranes } \\
\hline $\mathrm{DiaC}_{27} \beta \alpha(\mathrm{S} / \mathrm{R})$ & $13 \beta(\mathrm{H}), 17 \alpha(\mathrm{H})$-20S-diacholestane & $\mathrm{C}_{27} \mathrm{H}_{48}$ \\
\hline $\mathrm{DiaC}_{28} \beta \alpha(\mathrm{S} / \mathrm{R})$ & 24-methyl-13 $\beta(\mathrm{H}), 17 \alpha(\mathrm{H})$-20S-diacholestane & $\mathrm{C}_{28} \mathrm{H}_{50}$ \\
\hline $\mathrm{DiaC}_{29} \beta \alpha(\mathrm{S} / \mathrm{R})$ & 24-ethyl-13 $\beta(\mathrm{H}), 17 \alpha(\mathrm{H})$-20S-diacholestane & $\mathrm{C}_{29} \mathrm{H}_{52}$ \\
\hline
\end{tabular}

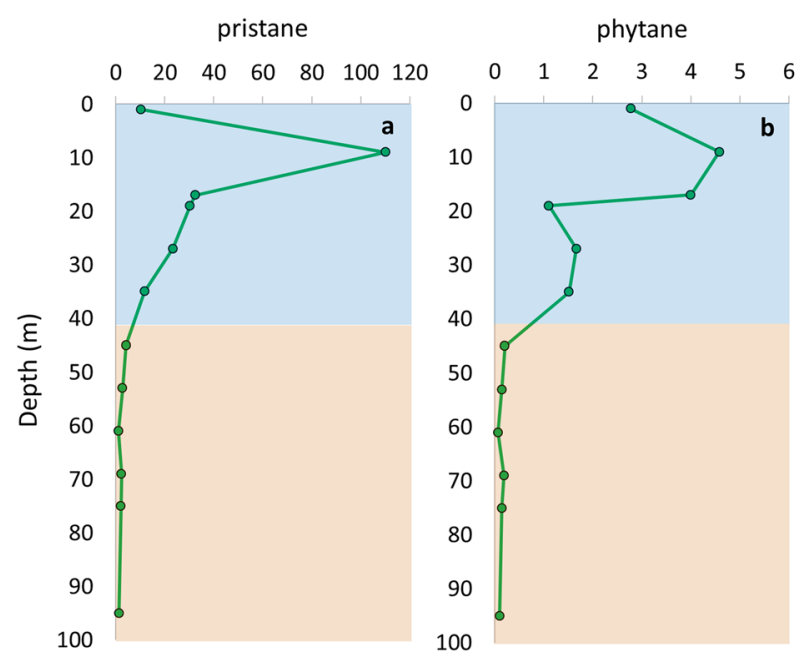

Fig. 4 Depth distribution of the four isoprenoids detected in the ESF core ( $\mu \mathrm{g} \mathrm{g}^{-1}$ of TOC), where the halite and detrital units are respectively represented by shaded blue and shaded orange areas. (Color figure online)

samples. In addition, we found that the deeper sample (i.e. $95 \mathrm{~m}$ ) was depleted in $\mathrm{R}$ versus $\mathrm{S}$ hopane epimers (Fig. 6c; Table S9), as well as in long alkyl hopanoids (e.g. tetrakishomohopanes or $4 \mathrm{HH}$ ) relative to the $\mathrm{C}_{30}$ hopane $(\mathrm{H})$ (Table 2). These hopanoid signatures are typically observed in petroleum highly degraded by bacterial processes (Aeppli et al. 2014).
LDChip-detected polymeric microbial markers along the ESF drill core

The LDChip200 identified the presence of biomolecules and polymeric material from prokaryotic sources on all the ESF sample extracts ("Multiplex fluorescent sandwich-microarray immunoassay" section). The 
Fig. 5 Top view of a GC $\times$ GC chromatogram of the a hopanes (m/z 191), and b, c steranes $(\mathrm{m} / \mathrm{z} 217$ and 218 , respectively) regions in sample at $95 \mathrm{~m}$ depth with identified compounds (see Table 2 for full names). The chromatograms are plotted as heat maps, where warmer colours correspond to larger signal intensity (i.e. peaks) on the two-dimensional chromatographic plane. See Fig. $6 \mathrm{~b}$ for a threedimensional representation of (a). (Color figure online)
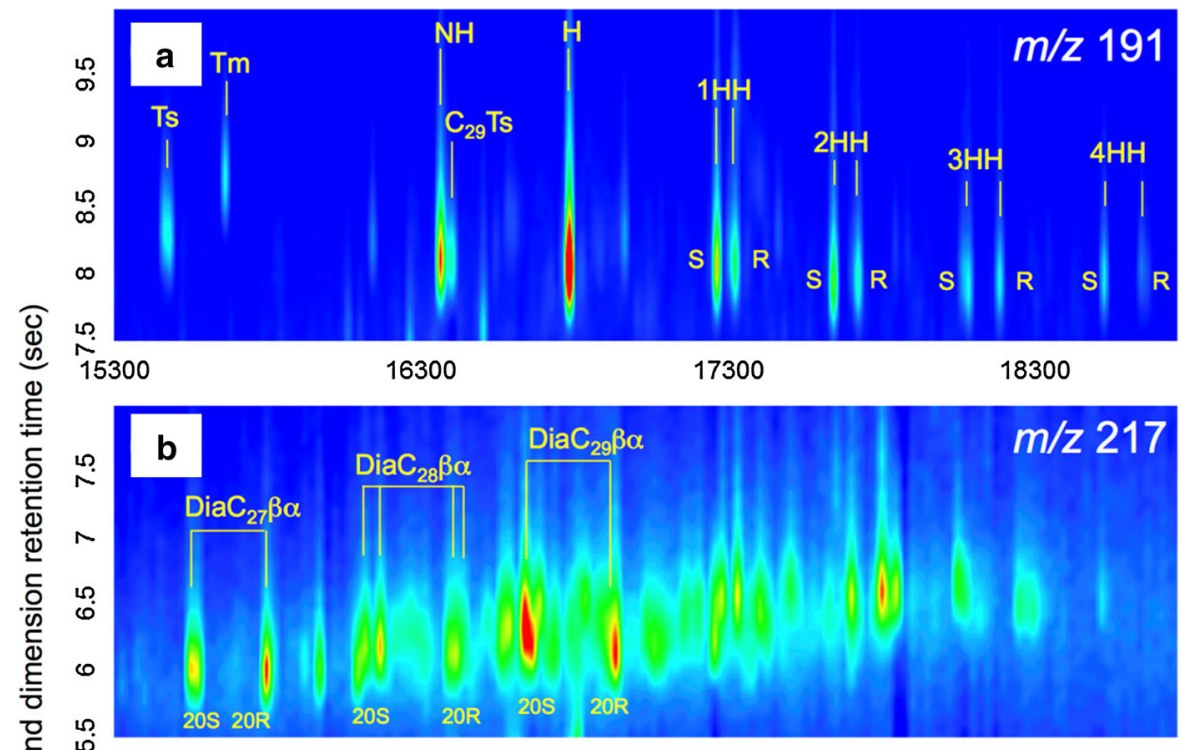

ठ্ঠ

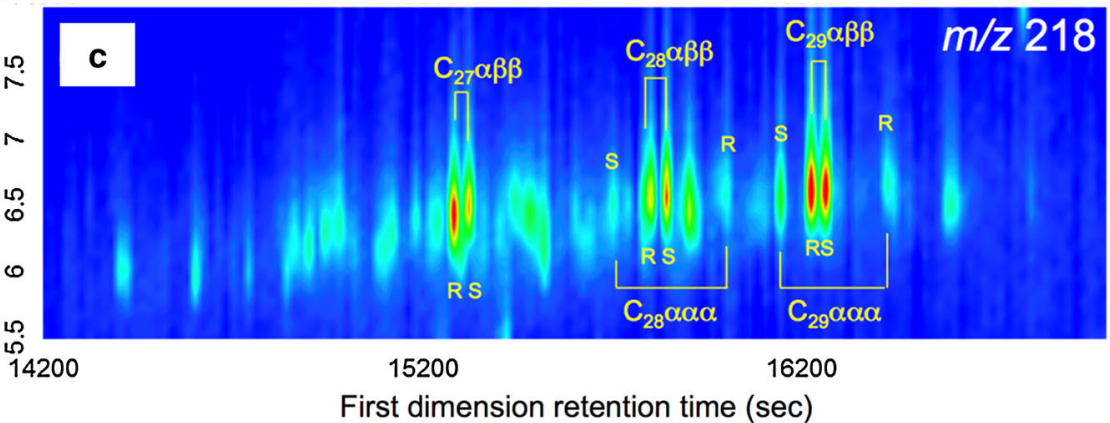

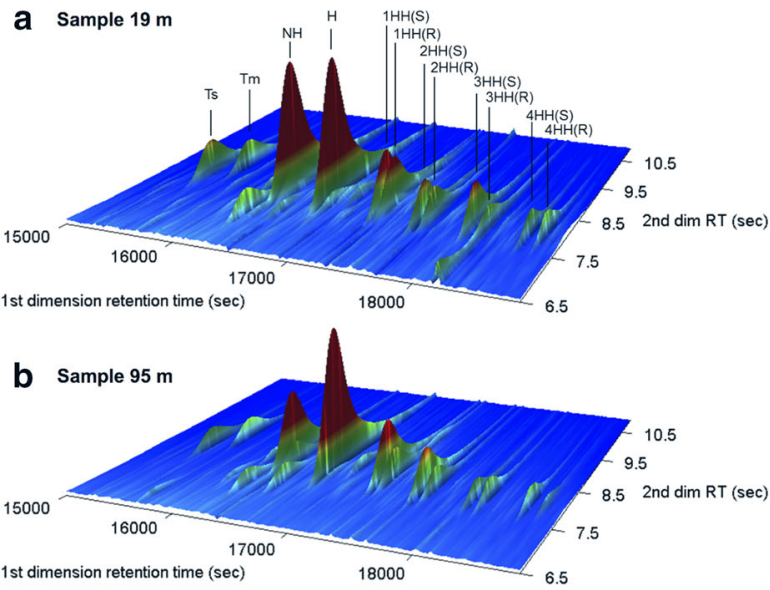

Fig. 6 Differential distribution of hopanoids in the halite versus detrital units. a, b Mountain-view of a $\mathrm{GC} \times \mathrm{GC}$ chromatogram at $\mathrm{m} / \mathrm{z}, 191$ and c biodegradation ratios of hopanoids, where preferential degradation of $R$ versus the $S$ hopanoids epimers (top) and of long alkyl hopanes versus C30

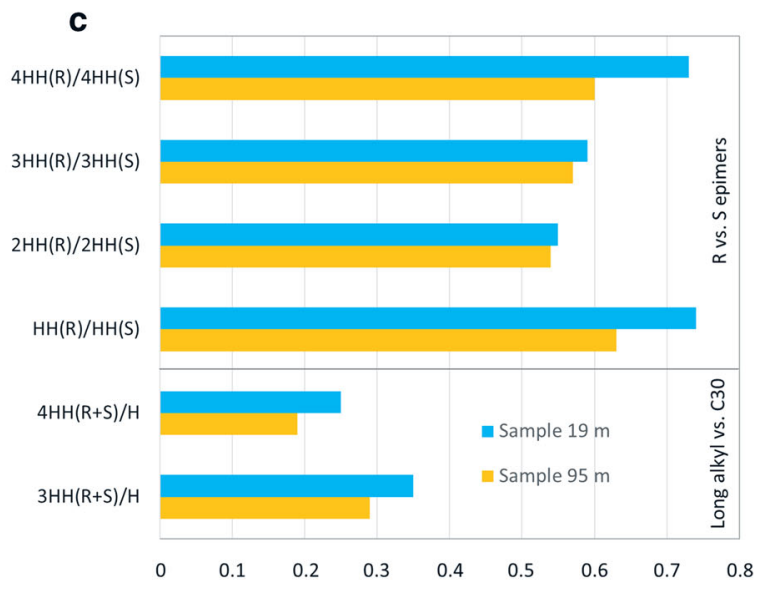

hopanes (bottom) is observed (see Table S9). Please note that no scale is represented for the $\mathrm{Y}$ axis in $\mathbf{a}$ and $\mathbf{b}$, according to the semi-quantitative analysis ("Steroids and Hopanoids" section) aiming to illustrate the qualitative differences between the two samples 
results were shown on a heat map (Fig. 7), where the color code is proportional to the relative fluorescence intensity (Fig. S5). Several antibodies showed immuno-detection of microbial markers from bacterial and archaeal strains belonging to different phylogenetic groups, proteins and peptides related with different metabolisms or response to environmental stress, cell extracts from salt-rich and iron-sulfur rich environmental samples, or even haloviruses extracts from solar saltern (Table S1). The larger number of immuno-detections corresponded to antibodies to Gammaproteobacteria strains (including sulfide

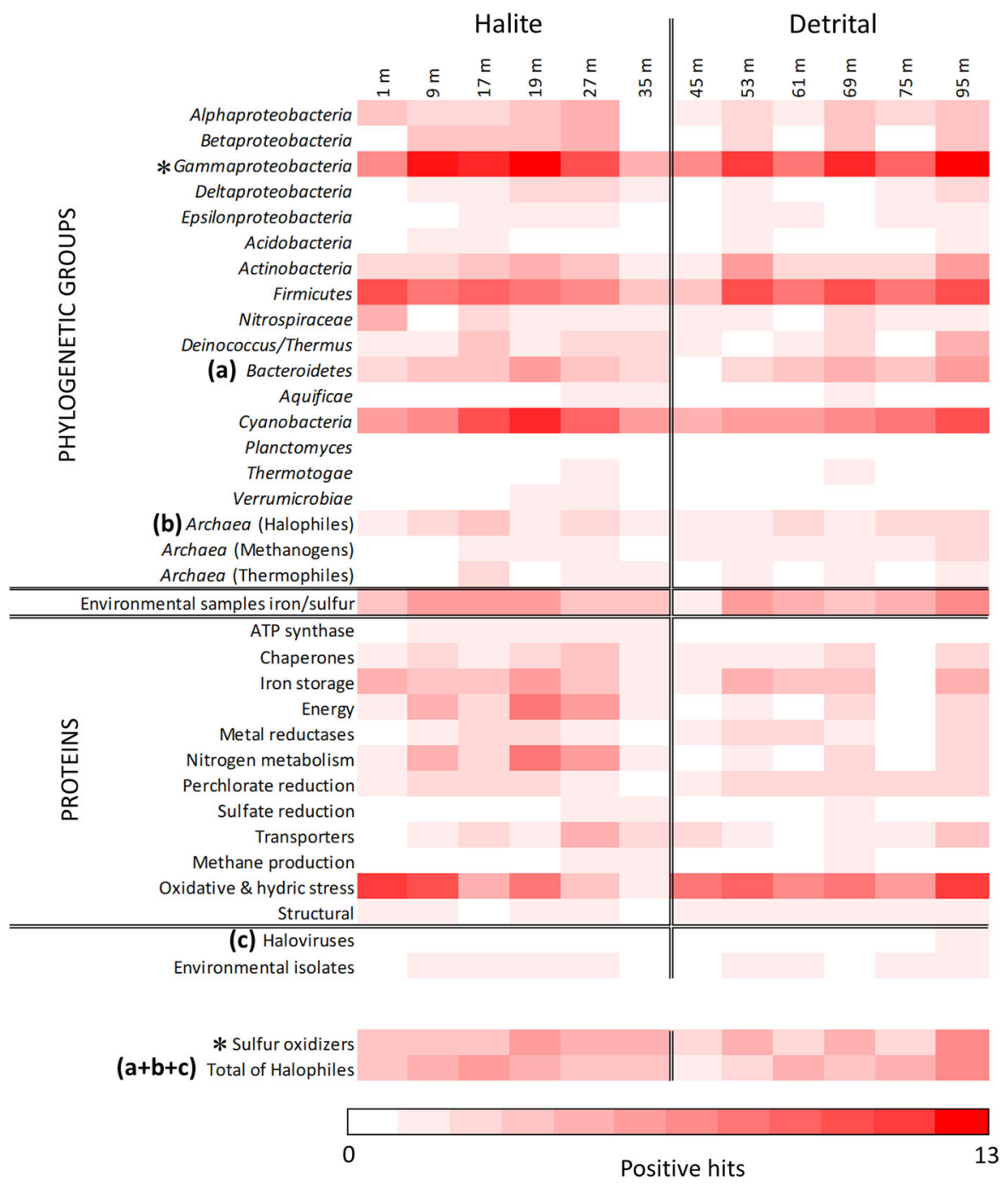

Fig. 7 Heat map showing the results obtained with the LDChip200 immunoassay in the Salar Grande ESF drill. The antibodies from Table S1 were clustered by phylogeny of the targets, proteins function, or environmental origin. Positive hits for each group were plotted in a scale from white (negative results) to red (maximum of 13 positive antibodies). At the bottom, the positive hits corresponding to sulfur oxidizers and halophilic organisms are featured. The asterisk (*) stands for the positive hits to sulfur oxidizers corresponding to 13 out of the 27 antibodies to Gammaproteobacteria (i.e. Acidithiobacillus ferrooxidans, A. thiooxidans, A. albertensis, A. caldus and Halothiobacillus neapolitanus; see Table S1). The total of halophiles in the last row correspond to the addition of positive hits of (a) three antibodies against a halophilic bacteria (Salinibacter ruber) included within the Bacteroidetes group, (b) three antibodies against halophilic Archaea (i.e. Haloferax, Halorubrum and Halobacterium), and (c) one antibody against a Salinibacter ruber viral preparation. Please notice that certain underestimation may result from representing the positive inmuno-detections in those groups with lower number of antibodies, such as halophilic microorganisms (i.e. only one to three antibodies versus up to 27 for Gammaproteobacteria). (Color figure online) 
oxidizers such as different species of Acidithiobacillus or Halothiobacillus neapolitanus), Gram-positive bacteria (Actinobacteria and Firmicutes, including spores), Cyanobacteria (including Nostoc, Anabaena or Microcystis spp.), Archaea (including halophiles of the genera Halorubrum and Halobacterium), cell extracts from environmental samples enriched in iron-sulfur oxidizer Gammaproteobacteria, or peptidic material associated with proteins involved in response to oxidative and hydric stress (Fig. 7, Fig. S5). Similarly, the LDChip200 detected halophilic bacteria such as Salinibacter spp. (Bacteroidetes) and bacteriophages (i.e. haloviruses in Fig. 7).

\section{Discussion}

Two well-differentiated geochemical units

The mineralogical analysis revealed two differentiated units in the ESF deposits (Fig. 2a), which generally agrees with previous geological descriptions by Chong-Diaz et al. (1999); the deeper deposits (40-100 m depth) of detrital origin composed of siliclastic materials (mainly albite and quartz), and the shallower deposits $(0-40 \mathrm{~m})$ of evaporitic origin mostly consisting of halite. Hereafter, we refer to the two mineralogical units as detrital and halite, respectively. In contrast to Chong-Diaz et al. (1999), here we integrated the surficial crust (top $2 \mathrm{~m}$ depth) described by them within the upper massive-halite deposits for simplicity purposes.

The differential origin of both units was reflected by various geochemical features. For instance, the amount of TOC was distinct in the halite versus the detrital unit (Fig. 3a). The halite deposits were generally depleted in TOC $(<0.3 \%)$, except for the most surficial layer (i.e. sample at $1 \mathrm{~m}$ depth) receiving additional organic inputs through percolation during episodic wetting and rain events (Chong-Diaz et al. 1999; Ewing et al. 2006; Wilhelm et al. 2017). However, despite the almost four times less TOC in the halite, the amount of lipidic biomarkers relative to TOC was about one order of magnitude larger in the upper than in the deeper detrital unit (Figs. 3, 4; see "Compositional differences in the Halite versus Detrital units based on molecular biomarkers" section). Apart from their different origin, little exchange is expected between the two geochemical units, as the well-cemented halite unit in hyperarid soils of Atacama act as an aquiclude (Ewing et al. 2006) preventing the transport of dissolved organic matter downward or the exposition of the detrital layers beneath to rainwater and other modern surficial processes, (Ewing et al. 2008). The generally depleted lipidic content of the most surficial sample relative to the other halite samples (Figs. 3, 4) was consistent with a negligible vertical exchange. From an inorganic point of view, the upper halite was almost exclusively composed of chloride, in contrast to the detrital unit characterized by the larger content of sulphate and nitrate (Fig. 2b-d). The distinct geochemical composition of both units may be related to the development (past or present) of different metabolic pathways, associated to nitrate or sulphate cycles in the detrital deposits, where both inorganic ions would act as electron acceptors for bacterial respiration with the support of electron donors (Chin and Janssen 2002) such as the acetate and propionate found (Fig. 2e).

Biomarkers-based source diagnosis in the Salar Grande subsurface at ESF

The lipidic and LDChip200 results revealed the presence of biomolecules at ESF with a majoritarian prokaryotic origin. Different microbial-diagnostic lipidic distributions documented the ubiquity of microbial vestiges throughout the ESF core. First, short-chain $n$-alkanes $\left(<\mathrm{C}_{20}\right)$ of general even-overodd predominance typically associated to microbial sources (Meyers and Ishiwatari 1993; Grimalt and Albaigés 1987) were generally detected at ESF (Fig. S1). Similarly, short-chain fatty acids $\left(\mathrm{C}_{12}-\mathrm{C}_{24}\right.$; Table S5) and $n$-alkanols $\left(\mathrm{C}_{10}-\mathrm{C}_{18}\right.$; Table S6) of even preference and majoritarian peaks at $\mathrm{C}_{16}$ and/or $\mathrm{C}_{18}$ were detected throughout the ESF profile (Fig. 3c, f). Second, branched fatty acids such as iso/anteiso $\mathrm{C}_{15}$ and $\mathrm{C}_{17}$ usually acknowledged to be produced by bacteria (Kaneda 1991) were generally measured in the ESF samples (Table S5). Other lipidic congeners of iso/anteiso configuration (i.e. 2-methyl and 3-methyl alkanes) most likely derived from the degradation of iso-/anteiso- fatty acids, were detected in the samples (Table S4) in relation to microbial imprints. In particular, short chain mono-methyl alkanes $\left(\mathrm{C}_{15}-\mathrm{C}_{20}\right)$ are described in microbial mat communities of hypersaline environments with dominance of cyanobacteria (Dembitsky et al. 2001). 
Third, the occurrence of monounsaturated fatty acids (Fig. 3e), mostly $\mathrm{C}_{16: 1}$ and $\mathrm{C}_{18: 1}$ (Table S5), may be also related to cyanobacteria among other bacterial sources (Cranwell 1978; Volkman et al. 1980). Forth, branched aliphatic alkanes with a quaternary substituted carbon atom (BAQCs) (i.e. 3,3- and 5,5diethyltridecane) were also measured at low concentration at a few depths $(61,69$, and $95 \mathrm{~m})$ in the detrital unit (Table S4). While the biological sources of the ubiquitous BAQCs are not well established, their particular abundance in ancient sediments has been associated with microbial mats (Simons et al. 2002), and more specifically with non-photosynthetic sulfide oxidizers (Kenig et al. 2003). Fifth, the generalized detection of different isoprenoids endorsed the hypothesis of a majoritarian microbial origin. For example, crocetane and squalane, indicative of the presence of Archaea, were detected in all samples but the most surficial (Fig. 4c, d). Crocetane is a diagnostic marker for methanogenic and methanotrophic Archaea (Brocks and Summons 2003), whereas squalane has been also used as biomarker for archaea in hypersaline depositional environments (Tornabene et al. 1979; Ten Haven et al. 1988; Grice et al. 1998). Its precursor squalene, although ubiquitous in sediments, it is considered to be majorly produced by archaea (Peters et al. 2005b), either methanogenic, halophilic or thermoacidophilic archaea (Tornabene et al. 1979; Stiehl et al. 2005). Pristane and phytane were also detected in all samples (Fig. 4a, b). They are biomarkers mainly originated from phytol (Brocks and Summons 2003), the esterifying alcohol of cyanobacterial and green-plant chlorophylls (Didyk et al. 1978), although they can alternatively derive from archaeols (Goosens et al. 1984; Brocks and Summons 2003), or from tocopherols (E vitamins; Goossens et al. 1984) in the case of phytane. Finally, the low steranes/hopanes ratios measured by GC $\times$ GC-TOF-MS ("Steroids and Hopanoids" section) also revealed the prevalence of prokaryotic (mainly bacteria) over eukaryotic sources (Peters et al. 2005b).

The LDChip200 results largely supported the microbial source of the lipid biomarkers and provided an estimation of the molecular diversity and relative biomass distribution within the ESF core. The LDChip200 immuno-detections revealed a generalized presence of microbial markers mostly from cell clusters or biofilm communities including bacteria, cyanobacteria, and archaea (Fig. 7). The strong signal in the immuno-detection of Cyanobacteria supported the source diagnosis from the measured mono-methyl alkanes (Table S4) and unsaturated fatty acids in almost all samples (Fig. 3e). The multiple antibodies showing positive detection of sulfur-oxidizer Gammaproteobacteria (Fig. 7, Fig. S5) were compatible with the presence of BAQCs in some ESF samples (Table S4). Finally, the immuno-detection of different archaeal strains corresponding to methanogens and haloarchaea (peaks 28-32 in Fig. S5) throughout the ESF profile (Fig. 7) was consistent with the ubiquitous detection of squalane, crocetane, or phytane (Fig. 4). In agreement, Gramain et al. (2011) found different species of haloarchaea (e.g. Halobacterium) in a 70-m salt core in the NE part of the Salar Grande that they explained by a combination of autochthonous production and transport from other hypersaline environments via wind or birds. They considered Halobacterium species as specialists at long-term survival in halite deposits in Salar Grande. According to these authors, the largest access to fresh inputs of nutrients related to deliquescent processes (Davila et al. 2008) makes the halite crusts a more attractive ecosystem than desert soil for phototrophic organisms.

Beside the majoritarian prokaryotic signature, certain lipidic distributions pointed to the contribution of additional sources such as higher plants, lichens and/or macrophytes. For instance, the presence of HMW nalkanes of typical odd-over-even preference (i.e. $\mathrm{C}_{27}$, $\mathrm{C}_{29}$, or $\mathrm{C}_{31}$ ) characteristic of higher plants (Eglinton and Hamilton 1967; Hedges and Prahl 1993) was observed at certain depths (19, 35, or 75 m; Fig. S1). The vegetal input was supported by the general detection of HMW $n$-fatty acids $\left(>n-\mathrm{C}_{20}\right)$ (Meyers and Ishiwatari 1993; Feng and Simpson 2007), with relevance of $\mathrm{C}_{22}$ and $\mathrm{C}_{24}$ (Fig. S2), and sterols majorly produced by higher plants (Bianchi 1995; Goad and Akihisa 1997), such as $\beta$-sitosterol and stigmasterol degradation products (Fig. 3h, Fig. S4). The occurrence of plant-derived lipids has been previously reported in other hyperarid soils in Atacama (i.e. Yungay; Wilhelm et al. 2017), together with $\mathrm{cm}$ long fragments of fibrous plant materials (Ewing et al. 2006). The finding of plant signatures in both hyperarid locations supports the argument for xeropreservation of plant-diagnostic lipids as plants are no longer living in the area since burial (Wilhelm et al. 2017). Moreover, the distribution of mid-chain $n$-alkanes $\left(\mathrm{C}_{20}\right.$ to $\left.\mathrm{C}_{25}\right)$ with a main peak at $\mathrm{C}_{23}$ at several depths 
$(27,35,53,61$, and $95 \mathrm{~m})$ was associated with the widespread lichen communities (Torres et al. 2003) thriving in the Salar Grande thanks to the limited daily water supply from the Camanchaca fog (e.g. Cheng et al. 2016). The most surficial sample (1 m depth) showed a heterogeneous distribution of $n$-alkanes with no clear main peak (Fig. S1) that denoted mixed contributions from algae, bacteria, lichens and/or macrophytes (Barnes and Barnes 1978; Grimalt and Albaigés 1987; Ficken et al. 2000; Torres et al. 2003). The larger accessibility of the top soil to atmospheric inputs (Wilhelm et al. 2017) and the periodical dissolution of the surface halite down to that depth as a consequence of the daily fogs and occasional rains (Chong-Diaz et al. 1999) may be relevant in determining its mixed lipidic signature.

Altogether, the lipidic molecular distributions and LDChip200 immuno-detections documented the ubiquitous presence of biological molecules of mostly microbial origin at ESF, with a minority contribution of vegetal sources.

Compositional differences in the Halite versus Detrital units based on molecular biomarkers

The widespread finding of labile functional groups of short residence time, together with the polymeric material detected by the antibodies, documented the generalized presence of microbial traces along the entire ESF profile, with noticeable differences in the halite versus detrital units. All lipidic biomarkers were found more abundant relative to TOC in the upper evaporites (Figs. 3, 4), where they showed maximum concentrations between 20 and $30 \mathrm{~m}$ and progressive decreasing trends towards the halite-detrital interface. In particular, the relative abundance of functional groups such as fatty acids (Fig. 3c-e), alkanols (Fig. 3f), or labile aldehydes (Fig. 3g) in the halite deposits illustrated the greater presence of microbial traces in the upper relative to the deeper detrital unit. Fatty acids are important building blocks of bacterial cell membranes, with significant proportion of those of LMW and even character, as well as iso/anteiso configuration (Kaneda 1991). They as well as alkanols tend to rapidly lose their functional group (i.e. carboxyl or hydroxyl, respectively) during diagenesis (Brocks and Summons 2004), becoming minority relative to their saturated homologues without active metabolisms or preservation. Although the origin of $n$ aldehydes is uncertain, the relative abundance of such a reactive group has been argued as indicative of greater microbial activity (Albaigés et al. 1984; del Río-Andrade 1989), either past (i.e. preserved) or present (i.e. extant biomass). This was supported by generally larger even- $\leq \mathrm{C}_{20}$ /odd $\geq \mathrm{C}_{27}$ ratios in the upper halite (Fig S3 a). The even- $\leq \mathrm{C}_{20}$ /odd $\geq \mathrm{C}_{27}$ ratio has been used as indicator of microbial activity (Sánchez-García et al. 2014; Vonk et al. 2012), as metabolism releases LMW $n$-alkanes with a strong even carbon number preference from processing of HMW homologues (Grimalt and Albaigés 1987). In contrast, the lower microbial vestiges in the detrital unit reflected the preservation of functionalized-fossil lipids, rather than active metabolisms, given the extremely limited microbial activity occurring for the past 2 My underneath massive halite deposits in the hyperarid Atacama soils (Ewing et al. 2008) and the little exchange between both layers (Ewing et al. 2006).

In a similarly hyperarid site in Atacama (i.e. Yungay), Wilhelm et al. (2017) explained a notable degree of preservation of functionalized fatty acids and other lipids over millions of years in terms of xeropreservation. In such hyperarid systems, the extremely low water availability hinders enzymatic activity and aerobic or anaerobic metabolisms (de Gomez-Puyou and Gomez-Puyou 1998; FernándezRemolar et al. 2013), and results in the preservation of labile compounds. Alternatively, mineral-organics interactions (Summons et al. 2011), entombment by chemical precipitates (Farmer and Des Marais 1999; Williams et al. 2015), or cellular modifications as survival strategies upon stress (Morgan et al. 2006) may also promote biosignatures preservation. In the ESF core, protective strategies based on mineralorganic interactions may be particularly relevant in the deeper detrital unit, where the presence of highlysorptive silicates was higher (i.e. albite and quartz; Fig. 2). In contrast, the larger content of salts in the halite deposits can play a role in the protection of active metabolisms or preservation of functionalizedfossil lipids by encasing the microorganisms or biomolecules during chemical precipitation inside fluid inclusions, as it has been described in other hypersaline environments (Conner and Benison 2013; Cheng et al. 2017). This role may also be relevant to astrobiology as the preservation of organics has been 
also described in extraterrestrial water-bearing salt crystals of millimetres size (Chan et al. 2018).

Beside the relative abundance of lipid functional groups in the halite relative to the detrital layers, compositional differences were also observed between the two geochemical units that enabled for some qualitative discussion. For instance, contrasting hopanoids composition of two halite and detrital samples pointed to different prokaryotic sources. The ratios of $\mathrm{R}$ over $\mathrm{S}$ epimers of $4 \mathrm{HH}, \mathrm{HH}, 3 \mathrm{HH}$, and $2 \mathrm{HH}$ hopanoids (Table S9) were always lower in the detrital than in the halite sample (Fig. 6c). Similarly, a slight depletion of long alkyl hopanoids such as tetrakishomohopanes $(4 \mathrm{HH})$, or trishomohopanes $(3 \mathrm{HH})$ relative to the $\mathrm{C}_{30}$ hopane $(\mathrm{H})$ was observed in the detrital (95 $\mathrm{m}$ depth) relative to the halite (19 $\mathrm{m}$ depth) sample (Fig. 6c). The preferential degradation of $\mathrm{R}$ versus $S$ hopanoid epimers (Aeppli et al. 2014) or long alkyl versus the $\mathrm{C}_{30}$ hopane (Munoz et al. 1997; Wang et al. 2001) have been described in geological samples in association to heavy microbial processing. In the ESF samples, the signature shift from the halite to the detrital sample was interpreted in terms of differential microbial sources, as confirmed by certain sourcespecific biomarkers such as the isoprenoids. The larger concentration relative to TOC of crocetane and squalane in the halite unit (Fig. 4c, d), decreasing toward the detrital deposits, illustrated a stronger archaea fingerprint in the halite. This was supported by a more intense immune detection against halophilic Archaea in the upper unit, whereas the immune signal against methanogenic Archaea was slightly stronger in the detrital unit (Fig. 7). Furthermore, greater presence of unsaturated fatty acids (Fig. 3e) and positive immuno-detection against cyanobacteria antibodies (Fig. 7) pointed to a broader representation of the Cyanobacteria phylum in the upper halite. Considering phytol as the prime source of pristane and phytane (Brocks and Summons 2003), the greater relative abundance of those isoprenoids in the halite unit (Fig. 4a, b) was linked also to the larger presence of cyanobacteria detected by the LDChip. In contrast, the limited detection of BAQCs in the detrital unit (Table S4), where sulphate was more abundant (Fig. 2c), was linked to sulfide oxidizers (Kenig et al. 2003), which presence was confirmed by the LDChip200 (Fig. 7).

The diverse molecular biomarkers (lipids and immuno-detections) described a generalized presence of microbial vestiges in the ESF depth profile, with quantitative and compositional differences in the halite versus the detrital units. The relative enrichment of each unit in chloride (halite) or nitrate and sulphate (detrital) may be crucial in the development of differential (past or present) metabolic pathways associated to the cycle of one or another inorganic ion. The greater detection of lipidic biomarkers in the halite deposits has implications for searching for potential evidences of life in planetary exploration (e.g. Mars or Europa). It is assumed that life selects and uses some basic molecules, although not necessarily the same basic set used by life on Earth (Mckay 2004). Thus, the detection in the ESF halite deposits of certain lipidic distributions (e.g. even and short chains, branched and unsaturated fatty acids, or isoprenoids) with characteristic biological patterns (Georgiou and Deamer 2014) contributes to interpret the GC/MS results from current and future missions in the search for biological patterns beyond the Earth, and, in the particular case of Mars, provides arguments for considering its evaporitic deposits as priority targets.

\section{Paleoenvironmental and astrobiological relevance}

The results obtained from the biogeochemical characterization of the ESF drill core had relevance for two complementary fields; paleogeochemistry and astrobiology. On the one hand, the geolipidic molecular distributions and LDChip200 findings provided valuable information that, taken together, allowed for reconstructing diverse paleoenvironmental aspects of Salar Grande at the ESF drill site (Fig. 8). For instance, the ubiquitous presence of squalane (Fig. 4d) and mono-methyl $n$-alkanes (Table S4), or the general immuno-detection of halophilic microbes such as Salinibacter, Halobacterium, Halorubrum, and Salinibacter-associated haloviruses (Fig. 7), is consistent with high salinity and periodic shallow water bodies in this environment (Chong-Diaz et al. 1999). The immuno-detection of Firmicutes, a phylum of bacteria well adapted to thrive in dry environments thanks to their resistance to desiccation because of the production of endospores, illustrated together with peptidic material related to proteins involved in resistance to oxidative and hydric stress (Fig. 7), the importance of developing strategies for thriving in the hyperarid Salar Grande. The general detection of $\mathrm{Pr} / \mathrm{Ph}$ ratios $>$ 1 throughout the entire drill (Fig. S3 b) supported the 


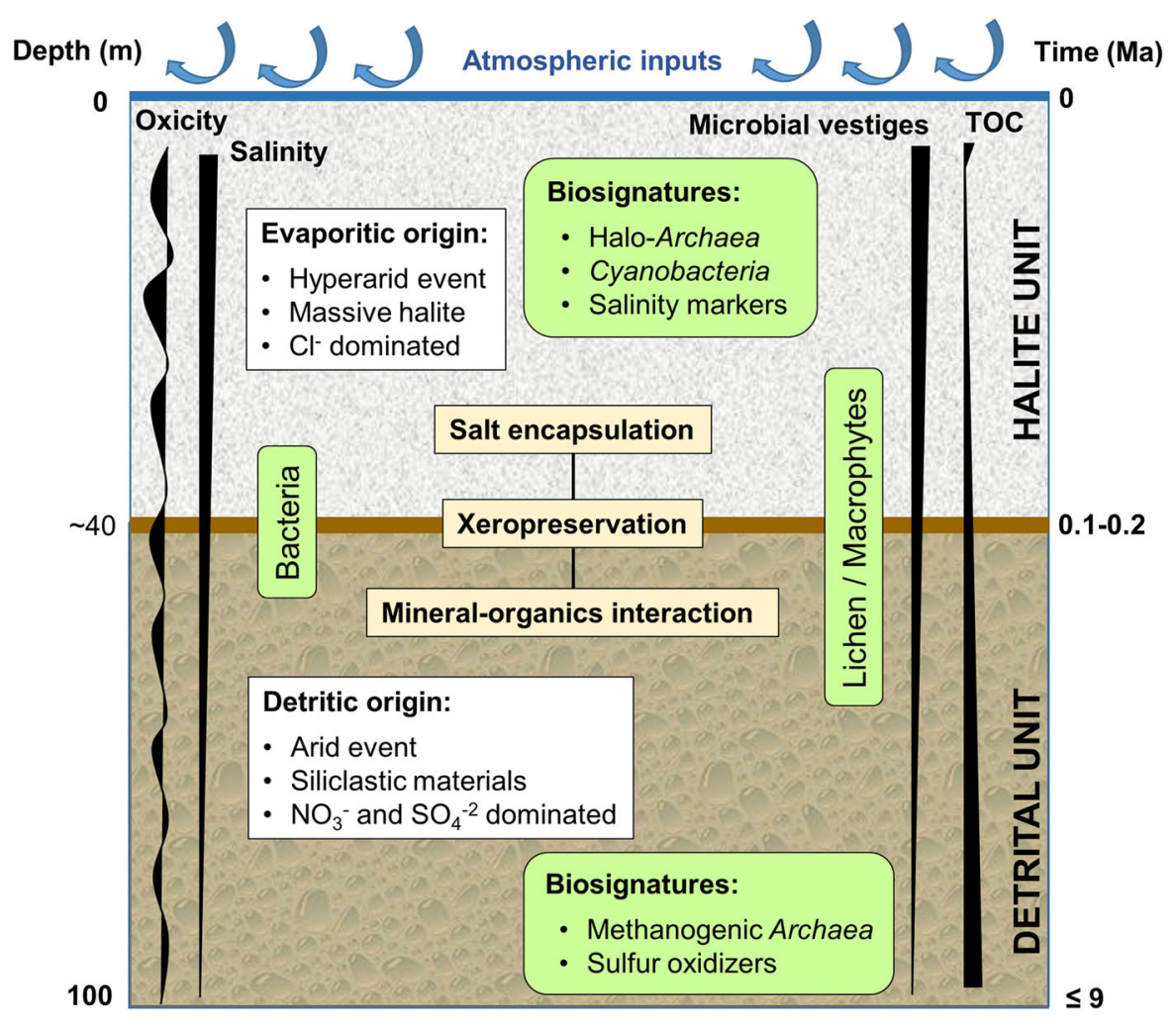

Fig. 8 Schematic of the paleoenvironmental reconstruction of the ESF drilling core at Salar Grande based on the lipid and LDChip200 findings. Key aspects on origin are synthetized in white boxes, dominant biosignatures in green rounded boxes, and protection/preservation strategies in pale yellow boxes. Relative variations of oxicity $(\mathrm{Pr} / \mathrm{Ph}$ ratio and Chong-Diaz et al. 1999), salinity, microbial vestiges, and TOC are depicted in black bars, as qualitative indicators. The dominant biosignatures are based on relatively larger detections of mono-methyl $n$ -

generally assumed oxic conditions dominating the formation of saline deposits at ESF (Chong-Díaz et al. 1999). The $\mathrm{Pr} / \mathrm{Ph}$ ratio is commonly used for the reconstruction of paleoredox conditions in ancient settings where pristane and phytane are considered to be derived from phytol (e.g. Didyk et al. 1978; Blumenberg et al. 2012). In this study, the larger variability of the ratio in the halite (3.7-27) versus the detrital unit (13-21) was construed as variation of the oxygen levels during the evaporite formation. These and other aspects including geochemistry, mineralogy, biological sources, and preservation strategies are compiled in Fig. 8, which illustrates the paleoenvironmental reconstruction of the ESF drilling site, based on the lipid and LDChip200 findings. Figure 8 schematizes how vestiges of past life may be alkanes, unsaturated fatty acids and immuno-detections (Cyanobacteria); crocetane and immuno-detections (methanogenic Archaea); squalane and immuno-detections (halophilic Archaea); branched alkanes with quaternary carbon (BAQCs) and immune-detections (sulphur oxidizers); even $n$-fatty acids, branched fatty acids, even $n$-alkanes, and immuno-detections (bacteria); as well as mid-chained $n$-alkanes (lichen/macrophytes). (Color figure online)

preserved on terrestrial paleorecords, retaining useful information for tracing early life.

On the other hand, the obtained results contribute to understanding the type of molecular biomarkers and their degree of preservation in an environment (i.e. hypersaline) that is relevant to the search for life in planetary exploration. Our work may contribute to the science that supports the search for signs of present or past life in current planetary exploration missions (e.g. the Mars Science Laboratory of the National Aeronautics and Space Administration, NASA) and future missions as ExoMars (European Space Agency), Mars2020 (NASA), or even the Europa Lander to the Jupiter's moon. At crater Gale sediments, the SAM (Sample Analysis at Mars) instrument on board the NASA rover Curiosity on Mars have detected 
$0.15-0.3 \mathrm{ppm}$ and $0.07 \mathrm{ppm}\left(\mu \mathrm{g} \mathrm{g}^{-1}\right)$ by weight of chlorobenzene and $\mathrm{C}_{2}-\mathrm{C}_{4}$ of dichloro-alkanes, respectively (Freissinet et al. 2015). These data imply that the TOC values expected are in the range of ppm in the analyzed samples. Considering the relatively high biomarker/TOC ratio found in the Salar Grande halite unit (Figs. 3, 4), we suggest evaporitic massive chloride deposits (Osterloo et al. 2010) as preferred candidates for future landing sites. In fact, the ExoMars and Mars2020 landing site candidates could eventually host small bodies of salts. The identification of microbial polymeric substances along the entire ESF drill indicated that either microbes (mainly bacteria and archaea) are still alive or they are very well-preserved, especially in the halite unit. If life ever had the opportunity to develop on Mars, subsurface briny environments maintained by deliquescent salts could host heterotrophic and chemolithoautotrophic prokaryotes. Similarly as in the Atacama Desert, halite crystals can permit sunlight filtered from UV radiation to penetrate where it can be used by phototrophic microbes (McGenity et al. 2000). The preservation potential of biomolecules in saline deposits of Mars could be even greater than Earth due to the combination of lower water activity, milder diagenesis, and very low temperatures (Fernández-Remolar et al. 2013). Under these circumstances, the saline deposits of Mars are exceptionally good targets for looking for biochemical evidences of life.

\section{Conclusions}

This study examined the presence and distribution of molecular biomarkers in hypersaline samples from a fossil lacustrine system in the Salar Grande, Atacama. An immunoassay-based life detector chip (LDChip200) revealed the presence of diverse high molecular weight-microbial markers associated to several phylogenies along the drill profile down to $95 \mathrm{~m}$ depth, indicating the presence of complex microbial communities and/or their remains. The molecular distribution patterns of lipidic biomarkers provided evidence of (mostly prokaryotic) life, either present or past, as well as proxies for origin and environmental reconstruction. The larger occurrence of labile congeners particularly susceptible to degradation such as branched and unsaturated fatty acids, or $n$-aldehydes, in the upper halite indicated larger preservation of microbial signatures, either as extant biomass or as functionalized-fossil lipids. This is a relevant finding for understanding life thriving and survival strategies in extreme (i.e. hyperarid and hypersaline) environments, both on Earth and other planets. The combined effect of xeropreservation with salt precipitation (halite unit) and/or organics-mineral interactions (detrital unit) were suggested as protection/preservation strategies of active metabolisms or fossilized biomarkers. Investigating the taphonomic strategies and distribution of molecular biosignatures in extreme environments on Earth, such as the Salar Grande, has implications for understanding equivalent processes of biomolecules preservation (if any) on Mars.

Acknowledgements We thank Maria Teresa FernándezSampedro for technical assistance in XRD. D. Carrizo and L. Sánchez acknowledge the Spanish Ministry of Economy and Competitiveness (MINECO/FEDER) for funding their respective projects RYC-2014-19446, and CGL2015-74254JIN). D. Fernández-Remolar acknowledges the Swedish National Space Board for funding partly his research in this work. Additional funding of the work was provided by the Spanish MINECO Project No. ESP2015-69540-R. V. Parro and D. Carrizo are co-Is of NASA Astrobiology Institute (NAI) CAN7 team Changing Planetary Environment and the Fingerprints of Life.

Open Access This article is distributed under the terms of the Creative Commons Attribution 4.0 International License (http:// creativecommons.org/licenses/by/4.0/), which permits unrestricted use, distribution, and reproduction in any medium, provided you give appropriate credit to the original author(s) and the source, provide a link to the Creative Commons license, and indicate if changes were made.

\section{References}

Aeppli C, Nelson RK, Radović JR, Carmichael CA, Valentine DL, Reddy CM (2014) Recalcitrance and degradation of petroleum biomarkers upon abiotic and biotic natural weathering of Deepwater Horizon oil. Environ Sci Technol 48:6726-6734

Albaigés J, Algaba J, Grimalt J (1984) Extractable and bound neutral lipids in some lacustrine sediments. Org Geochem 6:223-236

Allmendinger RW, González G (2010) Invited review paper: neogene to quaternary tectonics of the coastal Cordillera, northern Chile. Tectonophysics 495:93-110

ASTM (2000) Standard test methods for moisture, ash, and organic matter of peat and other organic soils. Method D 2974-00. American Society for Testing and Materials, West Conshohocken, PA 
Barnes MA, Barnes WC (1978) Organic compounds in lake sediments. In: Lerman A (ed) Lakes: chemistry, geology, physics. Springer, New York, p 363

Bianchi G (1995) Plant waxes. In: Hamilton RJ (ed) Waxes: chemistry, molecular biology and functions. The Oily Press, Dundee, pp 175-222

Blanco Y, Prieto-Ballesteros O, Gómez MJ, Moreno-paz M, García-Villadangos M, Rodríguez-Manfredi JA, Cruz-Gil P, Sánchez-Román M, Rivas LA, Parro V (2012) Prokaryotic communities and operating metabolisms in the surface and the permafrost of Deception Island (Antarctica). Environ Microbiol 14:2495-2510

Blanco Y, Quesada A, Gallardo-Carreño I, Aguirre J, Parro V (2015a) CYANOCHIP: An antibody microarray for hightaxonomical-resolution cyanobacterial monitoring. Environ Sci Technol 49:1611-1620

Blanco Y, Moreno-Paz M, Aguirre J, Parro V (2015b) Multiplex Fluorescent Antibody Microarrays and Antibody Graphs for Microbial and Biomarker Detection in the Environment. In: McGenity T, Timmis K, Nogales B (eds) Hydrocarbon and Lipid Microbiology Protocols. Springer Protocols Handbooks, Springer, Berlin, Heidelberg, pp 207-224

Blumenberg M, Thiel V, Riegel W, Kah LC, Reitner J (2012) Biomarkers of black shales formed by microbial mats, Late Mesoproterozoic (1.1 Ga) Taoudeni Basin, Mauritania. Precambrian Res 196-197:113-127

Brocks JJ, Summons RE (2003) In: Holland HD, Turekian KK (eds) Biogeochemistry. Elsevier, Amsterdam, pp. 63-115

Brocks JJ, Summons RE (2004) Sedimentary hydrocarbons, biomarkers for early life. In: Schlesinger WH (ed) Biogeochemistry: treatise on geochemistry, vol 8. Elsevier Pergamon, Oxford, pp 63-115

Brüggen J (1950) Fundamentos de la Geología de Chile. Instituto Geográfico Militar de Chile, Santiago de Chile, p 374

Chan QHS, ZolenskyM E, Kebukawa Y, Fries M, Ito M, Steele A, Rahman Z, Nakato A, Kilcoyne ALD, Suga H, Takahashi Y, Takeichi Y, Mase K (2018) Organic matter in extraterrestrial water-bearing salt crystals. Sci Adv. https:// doi.org/10.1126/sciadv.aao3521

Cheng ZY, Fernández-Remolar DC, Izawa MRM, Applin DM, Chong Díaz GM, Fernandez-Sampedro MT, García-Villadangos M, Huang T, Xiao L, Parro V (2016) Oxalate formation under the hyperarid conditions of the Atacama desert as a mineral marker to provide clues to the source of organic carbon on Mars. J Geophys Res-Biogeosci 121:1593-1604

Cheng Z, Xiao L, Wang H, Yang H, Li J, Huang T, Xu Y, Ma N (2017) Bacterial and archaeal lipids recovered from subsurface evaporates of Dalangtan Playa on the Tibetan Plateau and their astrobiological implications. Astrobiology. https://doi.org/10.1089/ast.2016.1526

Chin K-J, Janssen PH (2002) Propionate formation by Opitutus terrae in pure culture and in mixed culture with a hydrogenotrophic methanogen and implications for carbon fluxes in anoxic rice paddy soil. Appl Environ Microbiol 68:2089-2092

Chong G (1988) The Cenozoic saline deposits of the Chilean Andes between 18,000 and 27,000 south latitude. In: Bahlburg H, Breitkreuz Ch, Giese P (eds) The Southern
Central Andes. Lecture Notes Earth Sciences, vol 17. Springer, Heidelberg, pp 137-151

Chong-Diaz GM, Mendoza J, García-Veigas JJ, Pueyo Turner P (1999) Evolution and geochemical signatures in a Neogene forearc evaporitic basin: The Salar Grande (Central Andes of Chile). Palaeogeogr Palaeoclimatol Palaeoecol 151:39-54

Conner AJ, Benison KC (2013) Acidophilic halophilic microorganisms in fluid inclusions in halite from Lake Magic, Western Australia. Astrobiology 13:850-860

Cranwell PA (1978) Extractable and bound lipid components in a freshwater sediment. Geochim Cosmochim Acta 42:1523-1532

Crist-Christoph A, Gelsinger DR, Ma B, Wierzcho J, Ravel J, Davila A, Casero MC, DiRuggiero J (2016) Functional interactions of archaea, bacteria and viruses in a hypersaline endolithic community. Environ Microbiol 18:2064-2077

Davila AF, Gómez-Silva B, de los Rios A, Ascaso C, Olivares H, McKay CP, Wierzchos J (2008) Facilitation of endolithic microbial survival in the hyperarid core of the Atacama Desert by mineral deliquescence. J Geophys Res 113:G01028. https://doi.org/10.1029/2007jg000561

Davila AF, Duport LG, Melchiorri R, Jänchen J, Valea S, De Los Rios A, Fairén AG, Möhlmann D, McKay CP, Ascaso C, Wierzchos J (2010) Hygroscopic salts and the potential for life on mars. Astrobiology 10:617-628

De Gomez-Puyou MT, Gomez-Puyou A (1998) Enzymes in low water systems. Crit Rev Biochem Mol Biol 33:53-89

Deamer DW, Georgious CD (2015) Hydrothermal conditions and the origin of cellular life. Astrobiology 15:1091-1095

Del Río-Andrade JC (1989) Carácter geoquímico-orgánico de carbones de bajo rango de la cuenca miocénica de Granada. Dissertation, Universidad de Sevilla (Spain)

Dembitsky VM, Dor I, Shkrob I, Aki M (2001) Branched alkanes and other apolar compounds produced by the cyanobacterium Microcoleus vaginatus from the Negev Desert. Russ J Bioorg Chem 27:110-119

Didyk BM, Simoneit BRT, Brassell SC, Eglinton G (1978) Organic geochemical indicators of palaeoenvironmental conditions of sedimentation. Nature 272:216-222

Dunai TJ, González López GA, Juez-Larré J (2005) Oligocene-miocene age of aridity in the Atacama Desert revealed by exposure dating of erosion-sensitive landforms. Geology 33:321-324

Dundas CM, Bramson AM, Ojha L, Wray JJ, Mellon MT, Byrne S, McEwen AS, Putzig NE, Viola D, Sutton S, Clark E, Holt JW (2018) Exposed subsurface ice sheets in the Martian mid-latitudes. Science 359:199-201

Eglinton G, Hamilton JR (1967) Leaf epicuticular waxes. Science 156:1322-1335

Eiserbeck C, Nelson RK, Grice K, Curiale J, Reddy CM (2012) Comparison of GC-MS, GC-MRM-MS, and GC $\times$ GC to characterise higher plant biomarkers in Tertiary oils and rock extracts. Geochem Cosmochim Acta 87:299-322

Engel M, Macko S (1997) Isotopic evidence for extraterrestrial non- racemic amino acids in the Murchison meteorite. Nature 389:265-268

Ewing SA, Sutter B, Owen J, Nishiizumi K, Sharp W, Cliff SS, Perry K, Dietrich W, McKay CP, Amundson R (2006) A 
threshold in soil formation at Earth's arid-hyperarid transition. Geochim Cosmochim Acta 70:5293-5322

Ewing SA, Macalady JL, Warren-Rhodes K, McKay CP, Amundson R (2008) Changes in the soil C cycle at the aridhyperarid transition in the Atacama Desert. J Geophys Res 113:G02S90. https://doi.org/10.1029/2007jg000495

Farmer JD, Des Marais DJ (1999) Exploring for a record of ancient Martian life. J Geophys Res-Planets 104:26977-26995

Feng X, Simpson MJ (2007) The distribution and degradation of biomarkers in Alberta grassland soil profiles. Org Geochem 38:1558-1570

Fernández-Remolar D, Chong-Díaz G, Ruíz-Bermejo M, Harir M, Schmitt-Kopplin P, Tziotis D, Gómez-Ortíz D, GarcíaVilladangos M, Martín-Redondo MP, Gómez F, Rodríguez-Manfredi JA, Moreno-Paz M, de Diego-Castilla G, Echeverría A, Urtuvia VN, Blanco Y, Rivas L, Izawa MRM, Banerjee NR, Demergasso C, Parro V (2013) Molecular preservation in halite- and perchlorate-rich hypersaline subsurface deposits in the Salar Grande basin (Atacama Desert, Chile): Implications for the search for molecular biomarkers on Mars. J Geophys Res-Biogeosci 118:922-939

Ficken KJ, Li B, Swain DL, Eglinton G (2000) An $n$-alkane proxy for the sedimentary input of submerged/floating freshwater aquatic macrophytes. Org Geochem 31:749-754

Freissinet C, Glavin DP, Mahaffy PR, Miller KE, Eigenbrode JL, Summons RE, Brunner AE, Buch A, Szopa C, Archer PD, Franz HB, Atreya SK, Brinckerhoff WB, Cabane M, Coll P, Conrad PG, Des Marais DJ, Dworkin JP, Fairén AG, François P, Grotzinger JP, Kashyap S, ten Kate IL, Leshin LA, Malespin CA, Martin MG, Martin-Torres FJ, McAdam AC, Ming DW, Navarro-González R, Pavlov AA, Prats BD, Squyres SW, Steele A, Stern JC, Sumner DY, Sutter B, Zorzano M-P, the MSL Science Team (2015). Organic molecules in the sheep bed mudstone, Gale crater, Mars. J Geophys Res Planets 120:495-514

Gaines SM, Eglinton G, Rullkotter J (2009) Echoes of life: what fossil molecules reveal about earth history. Oxford University Press, New York

Georgiou CD, Deamer DW (2014) Lipids as universal biomarkers of extraterrestrial life. Astrobiology 14:541-549

Georgiou CD, Sun HJ, McKay CP, Grintzalis K, Papapostolou I, Zisimopoulos D, Panagiotidis K, Zhang G, Koutsopoulou E, Christidis GE, Margiolaki I (2015) Evidence for photochemical production of reactive oxygen species in desert soils. Nat Commun 6:7100. https://doi.org/10.1038/ ncomms 8100

Georgiou CD, Zisimopoulos D, Kalaitzopoulou E, Quinn RC (2017) Radiation driven formation of reactive oxygen species in oxychlorine containing Mars surface analogues. Astrobiology 17:319-336

Goad LJ, Akihisa T (1997) Analysis of sterols. Blackie Academic \& Professional, London

González-Vila FJ, Polvillo O, Boski T, Moura D, de Andrés JR (2003) Biomarker patterns in a time-resolved holocene/ terminal Pleistocene sedimentary sequence from the Guadiana river estuarine area (SW Portugal/Spain border).-. Org Geochem 34:1601-1613
Goossens H, de Leeuw JW, Schenck PA, Brassell SC (1984) Tocopherols as likely precursors of pristane in ancient sediments and crude oils. Nature 312:440-442

Gramain A, Chong-Diaz G, Demergasso C, Lowenstein TK, McGenity TJ (2011) Archaeal diversity along a subterranean salt core from the Salar Grande (Chile). Environ Microbiol 13:2105-2121

Grice K, Schouten S, Nissenbaum A, Charrach J, Sinninghe Damsté JS (1998) Isotopically heavy carbon in the $C_{21}$ to $\mathrm{C}_{25}$ regular isoprenoids in halite-rich deposits from the Sdom Formation, Dead Sea Basin, Israel. Org Geochem 28:349-359

Grimalt JO, Albaigés J (1987) Sources and occurrence of $\mathrm{C}_{12^{-}}$ $\mathrm{C}_{22}$ n-alkane distributions with even carbon-number preference in sedimentary environments. Geochim Cosmochim Acta 51:1379-1384

Hartley AJ, Chong G (2002) Late Pliocene age for the Atacama desert: implications for the desertification of western South America. Geology 30:43-46

Hedges JI, Prahl FG (1993) Early diagenesis: consequences for applications of molecular biomarkers. In: Engel $\mathrm{MH}$, Mecko SA (eds) Organic geochemistry, principles and applications. Plenum Press, New York, pp 237-253

Kaneda T (1991) Iso- and anteiso-fatty acids in bacteria: biosynthesis, function, and taxonomic significance. Microbiol Rev 55:288-302

Kenig F, Simons D-JH, Crich D, Cowen JP, Ventura GT, Rehbein-Khalily T, Brown TC, Anderson KB (2003) Branched aliphatic alkanes with quaternary substituted carbon atoms in modern and ancient geologic samples. PNAS 100:12554-12558

Martín-Torres FJ, Zorzano MP, Valentín-Serrano P, Harri AM, Genzer M, Kemppinen O, Rivera-Valentin EG, Jun I, Wray J, Madsen MB, Goetz W, McEwen AS, Hardgrove C, Renno N, Chevrier VF, Mischna M, Navarro-González R, Martínez-Frías J, Conrad P, McConnochie CC, Berger G, Vasavada A, Sumner D, Vaniman D (2015) Transient liquid water and water activity at Gale crater on Mars. Nat Geosci 8:357-361

Martrat B, Grimalt JO, Lopez-Martinez C, Cacho I, Sierro FJ, Flores JA, Zahn R, Canals M, Curtis JH, Hodell DA (2004) Abrupt temperature changes in the western Mediterranean over the past 250,000 years. Science 306:1762-1765

McGenity TR, Gemmell T, Grant WD, Stan-Lotter H (2000) Origins of halophilic microorganisms in ancient salt deposits. Environ Microbiol 2:243-250

Menor-Salván C, Tornos F, Fernández-Remolar D, Amils R (2010) Association between catastrophic paleovegetation changes during Devonian-Carboniferous boundary and the formation of giant massive sulfide deposits. Earth Planet Sci Lett 299:398-408

Meyers PA, Ishiwatari R (1993) Lacustrine organic geochemistry: an overview of indicators of organic matter sources and diagenesis in lake sediments. Org Geochem 20:867-900

Morgan CA, Herman N, White PA, Vesey G (2006) Preservation of microorganisms by drying; a review. J Microbiol Methods 66:183-193

Munoz D, Guiliano M, Doumenq P, Jacquot F, Scherrer P, Mille $G$ (1997) Long term evolution of petroleum biomarkers in mangrove soil (Guadeloupe). Mar Pollut Bull 34:868-874 
Navarro-González R, Rainey FA, Molina P, Bagaley DR, Hollen BJ, de la Rosa J, Small AM, Quinn RC, Grunthaner FJ, Cáceres L, Gomez-Silva B, McKay CP (2003) Mars-like soils in the Atacama Desert, Chile, and the dry limit of microbial life. Science 302:1018-1021

Osterloo MM, Anderson FS, Hamilton VE, Hynek BM (2010) Geologic context of proposed chloride-bearing materials on Mars. J Geophys Res-Planets. https://doi.org/10.1029/ 2010JE003613

Parro V, Rodríguez-Manfredi JA, Briones C, Compostizo C, Herrero PL, Vez E, Sebastián E, Moreno-Paz M, GarcíaVilladangos M, Fernández-Calvo P, González-Toril E, Pérez-Mercader J, Fernández-Remolar D, Gómez-Elvira J (2005) Instrument development to search for biomarkers on mars: Terrestrial acidophile, iron-powered chemolithoautotrophic communities as model system. Planet Space Sci 53:729-737

Parro V, Fernández-Calvo P, Rodríguez Manfredi JA, MorenoPaz M, Rivas LA, García-Villadangos M, Bonaccorsi R, González-Pastor JE, Prieto-Ballesteros O, Schuerger AC, Davidson M, Gómez-Elvira J, Stoker CR (2008a) SOLID2: an antibody array-based life-detector instrument in a Mars Drilling Simulation Experiment (MARTE). Astrobiology 8:987-999

Parro V, Rivas LA, Gómez-Elvira J (2008b) Protein microarrays-based strategies for life detection in astrobiology. Space Sci Rev 135:293-311

Parro V, Diego-Castilla G, Moreno-Paz M, Blanco Y, Cruz-Gil P, Rodríguez-Mandredi JA, Fernández-Remolar D, Gómez F, Gómez MJ, Rivas LA, Demergasso C, Echeverria A, Urtuvia VN, Ruiz-Bermejo M, García-Villadangos M, Postigo M, Sánchez-Román M, Chong-Díaz G, GómezElvira J (2011a) A microbial oasis in the hypersaline Atacama subsurface discovered by a life detector chip: Implications for the search of life on Mars. Astrobiology 11:969-996

Parro V, De Diego-Castilla G, Rodríguez-Manfredi JA, Rivas LA, Blanco-López Y, Sebastián E, Romeral J, Compostizo C, Herrero PL, García-Marín A, Moreno-Paz M, GarcíaVilladangos M, Cruz-Gil P, Peinado V, Martín-Soler J, Pérez-Mercader J, Gómez-Elvira J (2011b) SOLID3: a multiplex antibody microarray-based optical sensor instrument for in situ life detection in planetary exploration. Astrobiology 11:15-28

Peters KE, Walters CC, Moldowan JM (2005a) The Biomarker Guide-Part I. Biomarkers and Isotopes in the Environment and Human History, 2nd edn. Cambridge University Press, Cambridge

Peters KE, Walters CC, Moldowan JM (2005b) The biomarker guide-Part II-biomarkers and Isotopes in petroleum exploration and earth history, 2nd edn. Cambridge University Press, New York

Prieto-Ballesteros O, Fernández-Remolar DC, RodríguezManfredi JA, Selsis F, Manrubia SC (2006) Spiders: waterdriven erosive structures in the southern hemisphere of Mars. Astrobiology 6:651-667

Quinn RC, Martucci HF, Miller SR, Bryson CE, Grunthaner FJ, Grunthaner PJ (2013) Perchlorate radiolysis on Mars and the origin of martian soil reactivity. Astrobiology $13: 515-520$
Rivas LA, García-Villadangos M, Moreno-Paz M, Cruz-Gil P, Gómez-Elvira J, Parro V (2008) A 200-antibody microarray biochip for environmental monitoring: searching for universal microbial biomarkers through immunoprofiling. Anal Chem 80:7970-7979

Sáez A, Cabrera L, Jensen A, Chong G (1999) Late Neogene lacustrine record and palaeogeography in the QuillaguaLlamara basin, Central Andean fore-arc (northern Chile). Palaeogeogr Palaeoclimatol Palaeoecol 151:5-37

Sáez A, Cabrera L, Garcés M, Bogaard PVD, Jensen A, Gimeno D (2012) The stratigraphic record of changing hyperaridity in the Atacama desert over the last 10 Ma. Earth Planet Sci Lett 355-356:32-38

Sánchez-García L, Vonk J, Charkin A, Kosmach D, Dudarev O, Semiletov I, Gustafsson Ö (2014) Characterization of three regimes of collapsing Arctic ice complex deposits on the SE Laptev Sea coast using biomarkers and dual carbon isotopes. Permafrost Periglac Process 25:172-183

Simons D-JH, Kenig F, Critch D, Schröeder-Adams CJ (2002) Significance of novel branched alkanes with quaternary carbon centers in black shales. Geochim Cosmochim Acta 66:A718 abstr

Squyres SW, Grotzinger JP, Arvidson RE, Bell JF, Calvin W, Christensen PR, Clark BC, Crisp JA, Farrand WH, Herkenhoff KE, Johnson JR, Klingelhöfer G, Knoll AH, McLennan SM, McSween HY Jr, Morris RV, Rice JW, Rieder R, Soderblom LA (2004) In situ evidence for an ancient aqueous environment at Meridiani Planum, Mars. Science 306:1698-1703

Stiehl T, Rullkötter J, Nissenbaum A (2005) Molecular and isotopic characterization of lipids in cultured halophilic microorganisms from the Dead Sea and comparison with the sediment record of this hypersaline lake. Org Geochem 36:1242-1251

Summons RE, Amend JP, Bish D, Buick R, Cody GD, Des Marais DJ, Dromart G, Eigenbrode JL, Knoll AH, Sumner DY (2011) Preservation of martian organic and environmental records: final report of the Mars Biosignature Working Group. Astrobiology 11:157-181

Ten Haven HL, de Leeuw JW, Sinninghe Damste' JS, Schenck PA, Palmer SE, Zumberge JE (1988) Application of biological markers in the recognition of palaeo-hypersaline environments. In: Kelts K, Fleet A, Talbot M (Eds), Lacustrine petroleum source rocks. Blackwell, London, vol. 40, pp. 123-130

Tornabene TG, Langworthy TA, Holzer G, Oro J (1979) Squalenes, phytanes and other isoprenoids as major neutral lipids of methanogenic and thermoacidophilic archaebacteria. J Mol Evol 13:73-83

Torres A, Dor I, Rotem J, Srebnik M, Dembitsky VM (2003) Characterization of surface n-alkanes and fatty acids of the epiphytic lichen Xanthoria parietina, its photobiont a green alga Trebouxia sp., and its mycobiont, from the Jerusalem hills. Eur J Biochem 270:2120-2125

Volkman JK, Johns RB, Gillan FT, Perry GJ (1980) Microbial lipids of an intertidal sediment- - I. Fatty acids and hydrocarbons. Geochim Cosmochim Acta 44:1133-1143

Vonk JE, Sanchez-Garcia L, van Dongen BE, Alling V, Kosmach D, Charkin A, Semiletov IP, Dudarev OV, Shakhova N, Roos P, Eglinton TI, Andersson A, Gustafsson Ö (2012) 
Activation of old carbon by erosion of coastal and subsea permafrost in Arctic Siberia. Nature 489:137-140

Wang ZD, Fingas M, Owens EH, Sigouin L, Brown CE (2001) Long-term fate and persistence of the spilled Metula oil in a marine salt marsh environment-Degradation of petroleum biomarkers. J Chromatogr A 926:275-290

Wang Z, Yang C, Fingas M, Hollebone B, Yim UH, Oh JR (2006) Petroleum biomarker fingerprinting for oil spill characterization and source identification, In: Wang Z, Stout SA (Eds), Oil spill environmental forensics- fingerprinting and source identification. Academic Press, Burlington, San Diego, London, pp 73-146

Wilhelm MB, Davila AF, Eigenbrode JL, Parenteau MN, Jahnke LL, Liu X-L, Summons RE, Wray JJ, O’Reilly SS, Williams A (2017) Xeropreservation of functionalized lipid biomarkers in hyperarid soils in the Atacama Desert. Org Geochem 103:97-104

Williams AJ, Sumner DY, Alpers CN, Karunatillake S, Hofmann BA (2015) Preserved filamentous microbial biosignatures in the Brick Flat gossan, Iron Mountain, California. Astrobiology 15:637-668 